\title{
The role of intrinsic and extrinsic motivations in sharing economy post-adoption
}

\author{
Tiago Oliveira \\ (Nova Information Management School (NOVA IMS), Universidade Nova de Lisboa, Campus de \\ Campolide, Lisboa, Portugal) \\ lolanda Barbeitos \\ (Nova Information Management School (NOVA IMS), Universidade Nova de Lisboa, Campus de \\ Campolide, Lisboa, Portugal) \\ Antonela Calado \\ (Nova Information Management School (NOVA IMS), Universidade Nova de Lisboa, Campus de \\ Campolide, Lisboa, Portugal)
}

This is the author accepted manuscript version of the article published by Elsevier as:

Oliveira, T., Barbeitos, I., \& Calado, A. (2021). The role of intrinsic and extrinsic motivations in sharing economy post-adoption. Information Technology and People. https://doi.org/10.1108/ITP-01-2020-0007

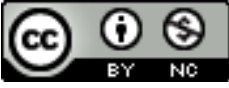

This work is licensed under a Creative Commons Attribution-NonCommercial 4.0 International License. 
Purpose: The paper examines use and sharing economy (SE) continuance intention, and the mediation effects of use between individuals' motivations and SE continuance intention. A theoretical model is developed to explain use and SE continuance intention as intrinsic and extrinsic motivated behaviour, as proposed by self-determination theory. Factors are derived from SE context and supported by published research on SE.

Design/methodology/approach: The Partial Least Squares Path Modelling (PLS-PM) technique is used to test the model in a quantitative study involving 256 users of SE services.

Findings: Findings suggest that use and SE continuance can be explained by concurrent intrinsic and extrinsic motivations. Moreover, high environmental concerns may restrain the use of sharing economy services. Findings show that continuance intention is influenced by current use of SE services. Moreover, the study emphasizes the mediation effect of use between intrinsic and extrinsic motivation and SE continuance intention.

Research limitations/implications: The analysis of use behaviour should be complemented with other measures of use and with data provided by qualitative methods of research. Further research should also consider the effect of different control variables and mediation effects.

Practical implications:

Brand managers and companies providing services through digital platforms should address individuals' needs in order to stimulate voluntary engagement in persistent SE practices.

Social implications: This study informs the consumer in general so that the sharing economy can develop its potential alongside an economy based on the ownership of private property.

Originality/value: This study extends findings on continuance intention research by offering internal motivation factors as predictors of post-adoption behaviour and emphasizes the role of use on SE continuance intention.

Keywords: sharing economy; collaborative consumption; continuance intention; self-determination theory; intrinsic motivations; extrinsic motivations. 


\section{The role of intrinsic and extrinsic motivations in sharing economy post-adoption}

\section{Introduction}

In recent years, individuals' preferences across the globe have shifted from product acquisition to the shared use of resources (Cohen and Kietzmann, 2014). Evidence comes from the 2017 PWC report on the $\mathrm{SE}$, which analyses the size and acceptance of the phenomenon in Austria, Belgium, Germany, the Netherlands, Switzerland, and Turkey. Media and entertainment have the most attractive offers for individuals, in which the highest usage rate is $28 \%$, followed by hotel and accommodation offers with a $20 \%$ usage rate.

Different sharing practices (bartering, second-hand purchases, reselling, swapping, lending and borrowing), are now being boosted and reinvented with the development of mobile communication technologies, especially when mediated by digital platforms. Their main role is to coordinate the transactions between individuals prepared to share their resources (service providers) to others prepared to pay to use them (consumers) (Cho et al., 2019). A viable and long-term successful digital platform relies upon a decentralized network of service providers and consumers (Frenken and Schor, 2017; Wang, Lin, et al., 2019; Xu and Gursoy, 2020). Therefore, understanding what motivates the use of SE services and continuance intention has become a fundamental research path and one that leads to the development of strategies to retain and win back profitable service providers and consumers (Kumar et al., 2018). Moreover, SE platforms (i.e. Airbnb) are particularly interested in individuals who exhibit both behaviours (share and use), as their presence expands community appeal to newcomers (Hermes et al., 2020) and increases demand from within the network providing it with greater capacity to service that demand (Lang et al., 2020). Furthermore, as the benefits of a given technology can be attained only through use and continued use (Bhattacherjee and Barfar, 2011; Shaikh and Karjaluoto, 2015), understanding the underlying motivation will help to better stimulate individuals' engagement with SE platforms and ultimately capitalize on the benefits promised by the SE.

Early empirical studies explore individuals' drivers to adopt SE practices (see Appendix A). Research on post-adoption behaviours in SE remains scarce (Hamari et al., 2015). In fact, few studies further examine use of SE services and continuance intention (see Table 1). If accessing users directly is typically a time consuming and costly task (Liang et al., 2018), the novelty of SE makes it even more difficult to assess users beyond the initial adoption stage. Academic contributions analysing use of SE services and continuance intention already shed some light on motives behind use (e.g. Lin, Wang, \& Wu, 2017) and continuance intention of service providers (e.g. Wang et al., 2020) and consumers (e.g. Shao et al., 2020). Additionally, studies focus on at least one specific sharing sector ranging from accommodation, transportation, energy (Tsou et al., 2019), and retail, or firm (usually Airbnb). To date, no study has addressed the use of SE services and continuance intention and sharing practices of access, renting, and selling, regardless of the product or service being shared. Furthermore, no study assesses the impact of use of the abovementioned sharing practices on continuance intention, explores mediation effects of use between individuals' motivations and their SE continuance intention. Therefore, our study seeks to fill these gaps by proposing and testing a research model tailored to SE context and anchored in selfdetermination theory (SDT). SDT has proven to be useful in explaining participation in SE (e.g., Hamari et al., 2015; Li \& Wen, 2019), and continued use of social networking tourism sites (French et al., 2017). However, existing research focuses on a limited set of motives. Moreover, SDT can be instrumental in fostering commitment (Ryan and Deci, 2000a), and should thus also be considered to explain continuance intention. The purpose of this study is (1) to explore the motivations behind use and SE continuance intention of three different sharing practices mediated by digital platforms: access to goods and services, 
and renting and selling personal goods, and (2) the mediation effects of use between individuals' motivations and SE continuance intention.

The study makes important contributions. First, it contributes to the academic literature on continuance intention in the context of the sharing economy. The relationship between use and continuance intention is already explored in IT continuance (Martins et al., 2019), but to our knowledge our contribution at the individual level is novel in the context of the sharing economy, namely in exploring the motivation to use SE services mediated by digital platforms allowing access to goods and services, renting, and selling privately owned property. Second, this study assesses in a holistic manner the direct and indirect effects of individuals' motivations on SE continuance intention and reports findings that are valuable to SE companies and brand managers. Recommendations for increasing the use of SE services and fostering individuals' long-term engagement in SE services are provided. Third, using SDT as a theoretical lens offers a deeper understanding of individuals' real needs and tackles the real reasons behind use and intention to continue to use SE services. Finally, our study informs consumers in general, so that SE can develop its potential alongside an economy based on ownership of private property.

We next provide an overview of the SE definitional issues, SE context, related literature on SE postadoption outcomes, and self-determination theory (SDT). The research model and hypotheses are then presented. Then, methods are provided including a quantitative survey to test the research model hypotheses. The paper ends with a discussion of the results, including implications for theory and practice, and further possible research directions are outlined.

\section{Theoretical Background}

\subsection{Sharing economy definition}

The sharing economy has been described as a "product-service system" (Mont, 2002), "collaborative consumption" (Botsman \& Rogers, 2010), "access-based consumption," (Bardhi and Eckhardt, 2012), "peer economy" (Bellotti et al., 2015) "gig-economy" (Cockayne, 2016), and "on-demand economy" (Friedman, 2014). Together, all these designations testify to the complexity of the phenomenon and the difficulty with respect to agreeing on its boundaries and impacts (Richardson, 2015).

The sharing economy is mainly viewed as an umbrella concept covering related phenomena such as "collaborative consumption" and "access-based consumption" (e.g. Chasin \& Scholta, 2015; Sach, 2015). An umbrella concept helps to connect phenomena but makes theorization difficult (Acquier et al., 2017). However, if the definition emphasizes only certain attributes of the phenomenon such as compensation or true sharing, some activities - peer production or commercial transactions - will be excluded from SE. Recent research proposes the use of organizational frameworks to avoid incomplete and dissenting definitions of the phenomenon, find a balance between extreme positions (e.g. Acquier et al., 2017; Ertz, Durif, \& Arcand, 2018; Martin, 2016), and shape a holistic portrait of SE (Davlembayeva et al., 2020). In order to position our work from academic and practical perspectives we use the organizational framework presented in Ertz, Durif, \& Arcand's (2018) work. Thus, we consider that participants in SE have the capacity to be both service providers and consumers; interaction is facilitated or mediated by a digital platform or an application and at a cost. We analyse three specific SE practices, namely access, renting, and selling.

\subsection{Sharing economy context}

Even though no commonly accepted definition of SE exists, researchers agree on some important features that shape the phenomenon (Cho et al., 2019; Ye et al., 2017). First, transactions comprise exchange of 
underused resources or resources with excess capacity. In fact, the rise of the SE is often linked to the 2008 global recession, which forced individuals to develop a preference for reusing and giving new purposes to their belongings and engaging in new arrangements to manage their possessions (Krush et al., 2015).

On the other hand, transacting underused resources emphasizes shared ownership (Zhang et al., 2018). While putting aside ownership and choosing access-only, individuals not only reduce time and effort with management and maintenance of personal property, this choice also provides easy access to products and services (Ertz et al., 2017). Consequently, costs are reduced, convenience is boosted, and access to products and services otherwise not accessible is gained (Sorensen, 2002).

Furthermore, transacting underused resources contributes to a more sustainable development. In fact, the benefits of these new resource-distribution practices go beyond the individual. While avoiding the destruction of value, SE practices also reduce waste. Sparing the use of scarce resources involved in the production of new products (e.g. Piscicelli et al., 2015; Stokes et al., 2014) seems to be a solution for problems such as overproduction and overconsumption (European Economic and Social Committee, 2014) affecting society.

Second, transactions are usually triadic exchanges (Benoit et al., 2017), including a digital platform (enables exchange), a service provider (individual prepared to share her/his underused resources), and a consumer (individual who needs the resource). Unlike traditional companies, companies managing SE platforms do not own or produce the goods or services being transacted and rely on resources of service providers to fulfil the needs of consumers Moreover, service providers and consumers are usually organized in communities rather than hierarchies as in traditional companies (Benkler, 2017). A robust community of individuals, capable of handling both supply and demand sides, is therefore vital for a successful sharing business (Kumar et al., 2018). Consumers and service providers are actively involved in the creation of value with the digital platform (Hermes et al., 2020). While service providers give information about themselves or the product or service being transacted, consumers leave comments rating their use experience, which involves the product or service and the service provider. Both benefit from network effects. Furthermore, individuals' roles evolve and service providers become consumers and vice-versa (Ertz et al., 2018; Lusch and Nambisan, 2015).

Third, trust is a feature of transactions in SE. As individuals transacting in SE are usually perfect strangers, transactions involve higher risks (Frenken and Schor, 2017). Digital platforms elicit trustworthiness of individuals using their services and of the resource being shared. Moreover, the digital platform is also subject to trust concerns (Hawlitschek, Teubner and Weinhardt, 2016).

Fourth, digital platforms rely on information technologies, the internet (Belk, 2014a), and ubiquity of mobile devices to coordinate interaction amongst service providers and consumers (Jiang and Tian, 2015). Technology is used to reduce the costs of transactions and to match up consumers and service providers in real time (Benkler, 2004; Mair and Reischauer, 2017). All communication between consumers and service providers is internet-mediated from first contact to payment (Gupta et al., 2019; Lu et al., 2019). Moreover, technology is also used by digital platforms to secure and legitimize transactions (Sutherland and Jarrahi, 2018), and also to boost trust amongst individuals and on the platform itself (Kumar et al., 2018). Smartphones and tablets offer permanent and speedy internet connection, generating flexibility and convenience for individuals partaking in SE, allowing them to choose when and how to participate, doing things more quickly and independently (Radka and Margolis, 2011). 
We contend that the SE context plays an important role in shaping individuals' use and continued use of SE services, i.e. the social, environmental, economic, and functional contexts provide the motives of use and SE continuance intention, as we will explain below.

\subsection{Related literature on sharing economy post-adoption outcomes}

We identified and analysed nine studies on SE post-adoption behaviours. Findings are summarized in Table 1. Use (Albinsson et al., 2019), positive word of mouth (Kong et al., 2020), recommendation and switch intention (Wang, Lin, et al., 2019), and SE continuance intention (Wang et al., 2020) are the postadoption behaviours addressed by recent SE research. Through a combination of factors and theories (see Table 1) sectors analysed by recent research include accommodation, transportation, and energy (Tsou et al., 2019). Specific SE services targeted by researchers include home sharing, bicycle sharing and car hailing, workspace sharing, technology and digital sharing. Airbnb is the platform most frequently targeted.

Only two studies focus on use as the dependent variable. Findings from (Lin et al., 2017) were anchored on the second extension of Unified Theory of Acceptance and Use of Technology and show that habit, facilitating conditions, and behavioural intention have significant positive effects on use behaviour. Albinsson, Perera, Nafees, \& Burman's (2019) study on the distinctive factors between collaborative consumption (CC) usage and collaborative consumption non-usage in the United States and Indian markets was informed by published research findings. Their study shows that perceived sustainability is the most important driver for CC use, followed by trust, possessiveness, generosity, risk-seeking, materialism, power distance, long-term orientation, and collectivism. Findings also point to similarities between $\mathrm{CC}$ users and non-users in both markets, suggesting the emergence of a global consumer.

Two main theories and respective extensions have been used to explain SE continuance intention. SE continuance intention is explained through the interaction between people and technology posited by social technical theory. Studies consider social and technical antecedents of trust to explain SE continuance intention (Kong et al., 2020; Wang et al., 2020). Findings from both studies suggest that together, social and technical enablers are important in the development of trust and that SE continuance intention is likely to depend upon the formation of trust. Other studies' main explanation for SE continuance intention relies on Expectation-Confirmation Theory (ECT) (Shao et al., 2020; Wang, Lin, et al., 2019). Both studies extend ECT by including antecedents of confirmation. The former included five service quality-related dimensions described in the SERVQUAL model and the latter included perceived risk.

We argue that these studies do not tackle the real reasons behind use and SE continuance intention. It is necessary to understand and address individuals' fundamental needs, and we suggest doing so by studying individuals' motivations to use SE services. Like Hamari et al. (2015) and Li \& Wen (2019), we adopt SDT as a theoretical lens (see next section). However, our set of motives influencing SE use is derived from the SE context besides being more comprehensive and supported by research. Also, we posit that greater use of SE services will lead to SE continuance intention. To the best of our knowledge no study has assessed this relationship and its contribution to explain SE continuance intention. Furthermore, no study explores mediation effects of use between individuals' motivations and their SE continuance intention. We address these gaps by presenting and testing a comprehensive framework in which motivation to use and SE continuance intention results from the combination of social, environmental, economic, and functional contextual factors. Our study provides the support that SE platforms need to maintain existing customers and build up a decentralized network who will make their business viable and successful in the long term. 
Table 1 - Research on post-adoption behaviours

\begin{tabular}{|c|c|c|c|c|c|c|}
\hline Study & \begin{tabular}{|l|} 
Dependent variable \\
\end{tabular} & Independent variable & Theoretical framework & Sharing services & Method & Sample \\
\hline French et al. 2017 & \begin{tabular}{|c|} 
Continued use \\
intention, atittude, \\
satisfaction, \\
bridging social \\
capital, bonding \\
social capital \\
\end{tabular} & $\begin{array}{l}\text { Economic value, } \\
\text { Networking value, } \\
\text { trust }\end{array}$ & \begin{tabular}{|c|} 
Theory of planned \\
behavior, Social \\
Capital, Self- \\
determination Theory
\end{tabular} & $\begin{array}{c}\text { SNETT - Social Network } \\
\text { Tourism Sites } \\
\text { (couchsurfing.com) }\end{array}$ & Interviews+survey & $\begin{array}{c}593 \\
\text { couchsurfing.com } \\
\text { users (survey) }\end{array}$ \\
\hline Lin, Wang \& Wu 2017 & $\begin{array}{c}\text { Use behavior, } \\
\text { behavioral intention }\end{array}$ & \begin{tabular}{|c|} 
Performance \\
expectancy, effort \\
expectancy, social \\
influence, facilitating \\
conditions, hedonic \\
motivation, price value \\
and habit \\
\end{tabular} & UTAUT 2 & $\begin{array}{l}\text { Acommodation } \\
\text { (Airbnb) }\end{array}$ & Survey & 408 Airbnb guests \\
\hline Na \& Kang, 2018 & \begin{tabular}{|} 
Behavior intention, \\
Shared value, \\
Distinctive \\
competitive \\
advantage
\end{tabular} & \begin{tabular}{|c|} 
Visibility, scarcity, \\
imperfectly imitable, \\
non \\
substitutable,socializat \\
ion, externalization, \\
integration, \\
internalization \\
\end{tabular} & Resource based theory & $\begin{array}{c}\text { consumers that have } \\
\text { used sharing economy } \\
\text { business services }\end{array}$ & Survey & $\begin{array}{c}534 \text { university } \\
\text { students and } \\
\text { office workers } \\
\text { that have used } \\
\text { sharing economy } \\
\text { services }\end{array}$ \\
\hline Albinson \& perera.,2019 & Use & \begin{tabular}{|c|} 
Perceived \\
Sustainability as the \\
strongest predictor of \\
usage followed by \\
Trust, Possessiveness, \\
Generosity, Risk- \\
seeking, Materialism, \\
Power Distance, Long- \\
term orientation and \\
Collectivism \\
\end{tabular} & $\begin{array}{l}\text { Based on extant } \\
\text { research findings on } \\
\text { CC. }\end{array}$ & \begin{tabular}{|} 
car/ride-hailing, bike- \\
sharing, and \\
home/accommodation \\
sharing, \\
technology/digital \\
sharing (e.g. music and \\
movie file sharing), \\
and workspace sharing
\end{tabular} & Survey & $\begin{array}{c}784 \text { consumer } \\
\text { panel in the U.S. } \\
\text { and a Marketxcel } \\
\text { consumer panel } \\
\text { in India }\end{array}$ \\
\hline Wang, Lin \& Liu, 2019 & \begin{tabular}{|c|} 
Rcomendation, Conti \\
nuance, Switch \\
intention, Service \\
Satisfaction, Service \\
Dissatisfaction, \\
Confirmation
\end{tabular} & $\begin{array}{l}\text { Perceived } \\
\text { Performance, } \\
\text { Perceived risk }\end{array}$ & $\begin{array}{l}\text { Expectation- } \\
\text { confirmation theory }\end{array}$ & Bycicle sharing services & Survey & $\begin{array}{c}460 \text { customers of } \\
\text { bicycle-sharing } \\
\text { services China }\end{array}$ \\
\hline Tsou, Chen, Chou and Chen, 2019 & $\begin{array}{c}\text { Continued sharing } \\
\text { energy intention, } \\
\text { Utilitarian value, } \\
\text { Hedonic value }\end{array}$ & Service experience & Dramaturgical theory & $\begin{array}{l}\text { Energy network } \\
\text { (Gogoro) }\end{array}$ & $\begin{array}{c}\text { Survey (paper and } \\
\text { web based) }\end{array}$ & $\begin{array}{c}460 \text { Taiwanese } \\
\text { users of Gogoro } \\
\text { energy sharing } \\
\text { services }\end{array}$ \\
\hline kong et al., 2020 & $\begin{array}{c}\text { Continued use and } \\
\text { positive word-of } \\
\text { mouth, trust }\end{array}$ & $\begin{array}{l}\text { Social referrals, } \\
\text { information quality, } \\
\text { transaction safety }\end{array}$ & Socio-technical theory & Accomodation (Airbnb) & Survey & $\begin{array}{c}211 \text { active Airbnb } \\
\text { millenial users }\end{array}$ \\
\hline Shao,Li, Guo \& Zhang 2020 & $\begin{array}{l}\text { Continuance } \\
\text { intention, } \\
\text { Satisfaction, } \\
\text { Confirmation, } \\
\text { Perceived } \\
\text { usefulness } \\
\end{array}$ & \begin{tabular}{|} 
Location Reliability, \\
Prompt Response, \\
Transaction Assurance, \\
customization and \\
vivid apearance
\end{tabular} & $\begin{array}{c}\text { Service quality theory, } \\
\text { Expectancy } \\
\text { confirmation theory }\end{array}$ & $\begin{array}{l}\text { Dockless Bycicle } \\
\text { sharing services }\end{array}$ & Survey & $\begin{array}{c}437 \text { users of } \\
\text { dockless bycicle } \\
\text { sharing services }\end{array}$ \\
\hline Wang et al., 2020 & $\begin{array}{l}\text { Continuance } \\
\text { intention, trust }\end{array}$ & \begin{tabular}{|c|} 
User experience, \\
Social utility of \\
sharing, System \\
quality, Service \\
quality, Information \\
quality, Extrinsic \\
reward, Perceived \\
effectiveness of \\
industry self- \\
regulation, perceived \\
effectiveness of \\
privacy policy \\
\end{tabular} & $\begin{array}{c}\text { Sociotechnical theory } \\
\text { and the information } \\
\text { systems success } \\
\text { model, privacy } \\
\text { concerns and economic } \\
\text { value perspectives }\end{array}$ & Accomodation (Airbnb) & Survey & $\begin{array}{c}606 \text { active Airbnb } \\
\text { hosts }\end{array}$ \\
\hline
\end{tabular}

\subsection{Self-determination theory (SDT) and the sharing economy}

In order to understand use and SE continuance intention, individuals' motivations must be taken into consideration. SDT has proven to be relevant in explaining participation in SE (e.g. Hamari et al., 2015; Li \& Wen, 2019) and it can be instrumental in fostering commitment (Ryan and Deci, 2000a) and thereby help to explain use and continued use intention among individuals using SE services. SDT focuses on human motivation and personality. Developed by psychologists Edward Deci and Richard Ryan, this theory suggests that voluntary and persistent behaviours, emanating from individuals' sense of self, are determined by the needs for competence (comparable to Bandura's self-eficacy (2001)), relatedness (the need to feel supported by important people such as family, peers, or supervisors), and autonomy (the 
desire to self-organize one's actions). Individuals become self-motivated when they experience all three. Self-determined behaviour is considered more efficient and voluntarily persistent (Ryan and Deci, 2000a).

SE services represent an alternative to traditional modes of consumption, offering an option over ownership. It is a choice that makes individuals less dependent on companies and allows access to products and services otherwise not accessible (Radka and Margolis, 2011). Individuals interact directly with each other, forming a non-hierarchical community in which members rely on the opinions of strangers of reference and less on advertising (Radka and Margolis, 2011). Securing behaviour on the opinions of the majority facilitates decision making and integration in the community (Zhao et al., 2018). Moreover, individuals face fewer barriers to participate when compared to traditional labour markets. They can choose to participate at need, and often have the chance to self-organize their time and activities (Sutherland and Jarrahi, 2018). SE services thus empower individuals, whose decision making is supported within SE communities and who can then act more freely, self-directing own action. Consequently, SE services satisfy the three basic needs mentioned above.

SDT distinguishes between intrinsic and extrinsic motivated behaviours. Intrinsic motivated behaviour is performed simply because it is innately stimulating or pleasing (Ryan and Deci, 2000b) and is deeply connected with internal psychological processes such as self-fulfilment and achievement. Lindenberg (2001) argues that an individual is not only enjoyment-driven but also obligation-driven. Hence, the need to act appropriately, based on principles and reflecting social norms, is also a type of intrinsic motivation.

Individuals using SE services mediated by digital platforms experience joy and emotional pleasure (Li and Wen, 2019), but also satisfy philanthropic needs by reducing waste and saving resources when giving new purposes to their underutilized belongings (Hwang and Griffiths, 2017; Li and Wen, 2019). Moreover, using SE services helps individuals to deal with the ethical concern of loss of value, when there is the recurrent thought that the product sitting idle could be of use to someone else (Radka and Margolis, 2011). At the same time, individuals transacting in SE also experience a sense of belonging (Möhlmann, 2015), as they become part of a community that they wish to relate to and join (Radka and Margolis, 2011). They seek opinions they respect in search of things they personally value, by relying on friends and trusted sources (Shmidt, 2020). Trust is a psychological expectation governing all interactions, a safeguard of transactions between perfect strangers (Frenken and Schor, 2017). Therefore, social and environmental contexts are rich in factors that are deeply connected with internal and psychological processes of the individual and that determine intrinsic motivated behaviour. Consequently, in our study, factors determining intrinsic motivated behaviour include enjoyment, trust, sense of community, social influence, and sustainability.

According to SDT, individuals' behaviour is not only intrinsically motivated. Unlike intrinsic motivated behaviour, extrinsic motivated behaviour is externally driven, as it is performed because it leads to a distinct outcome. Presumed value is associated to some outcome detached from the behaviour (Ryan and Deci, 2000b). Extrinsically motivated behaviour can be performed without deliberately valuing the behavioural goal, i.e., to respond an external demand, achieve an externally imposed reward, avoid guilt or anxiety, and demonstrate self-worth and value (Ryan and Deci, 2000a). Extrinsic motivated behaviour can also reflect personal importance attributed to a behaviour and its acceptance or total assimilation by the self. Expectations of economic rewards and monetization of assets (in the case of hosts), as well as utility are external consequences of using SE services. Economic and utilitarian rewards benefit either individuals who use SE services without truly believing in its advantages as a sustainable form of consumption, and those who see it as a solution to overconsumption. Technological factors (internet and mobile device) reinforce and facilitate the sense of flexibility and convenience (Radka and Margolis, 2011). Therefore, economic and functional contexts are rich in valuable external outcomes resulting from choosing SE services and that determine extrinsic motivated behaviour. Consequently, in our study, 
factors determining extrinsic motivated behaviour include economic benefits and monetization, utility, internet capability, and mobile device capability.

\section{Research model and hypotheses}

This study seeks to explain use and SE continuance intention, the two dependent variables of our study. SE continuance intention is defined as an individual's likelihood of continuing to use SE services.

We posit that individuals use behaviour in SE is determined by intrinsic and extrinsic motivations. Likewise, we posit that the same intrinsic and extrinsic motivations explaining use also lead to SE continuance intention. SDT is the theoretical lens chosen to theorize the relationship between individuals' motivations use of SE services and SE continuance. Moreover, according to SDT, after experiencing the benefits of use individuals are more likely to voluntarily engage in persistent SE practices, and consequently we posit that greater use of SE services will increase the likelihood of continued use of SE services. Exploration of use mediation effects between the chosen set of motives and SE continuance intention is also tested. The research model is shown in Figure 1.

Figure 1 - The research model

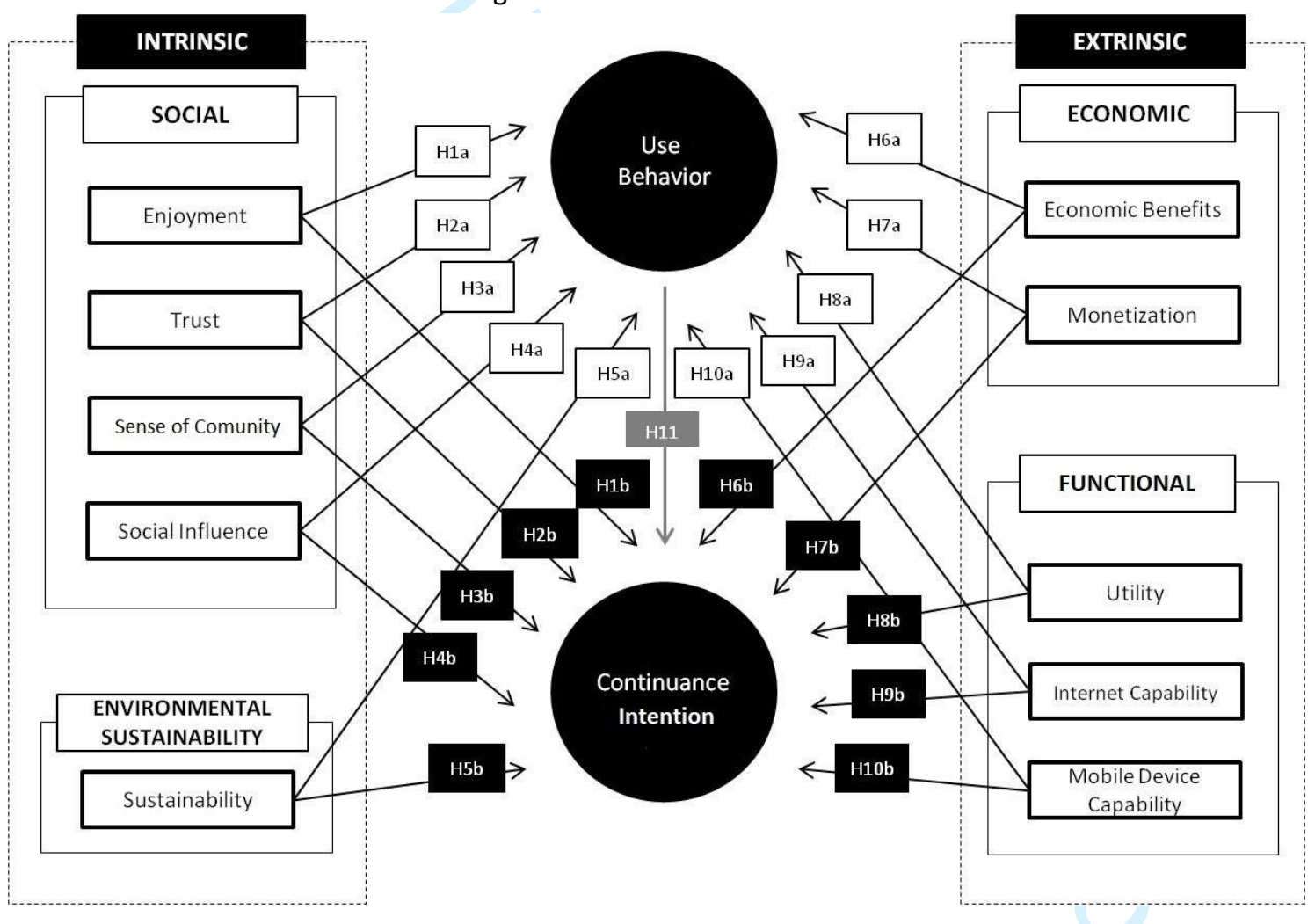

\subsection{Social context hypotheses}

Enjoyment is defined as the degree to which the activity of using a specific system is perceived to be pleasing and entertaining, regardless of any performance consequences resulting from system use (adapted from Venkatesh, 2000). Individuals using SE services available on an SE platform are not drawn to a website or app by potential economic or financial benefits only (Ek Styvén and Mariani, 2020; Shmidt, 2020; Xu and Schrier, 2019). Individuals using SE services mediated by digital platforms seek multi-sensory and emotional aspects while using a sharing service (Hwang and Griffiths, 2017), namely fun, enjoyment, and fantasy (Liu et al., 2020). For instance, a consumer of accommodation services may choose between 
several types of accommodation on Airbnb: apartments, treehouses, houseboats, tents and tepees, old barns, castles, or even a blockbuster video store. The variety of options presented by Airbnb aims to produce a fun and memorable experience (Hwang and Griffiths, 2017) as opposed to an interesting shopping task. Previous research has shown that the enjoyment of interacting with others and contributing to the community has a positive effect on behavioural intentions in SE (Barnes and Mattsson, 2017; Bellotti et al., 2015; Hamari et al., 2015; Li and Wen, 2019; Lin et al., 2017; Tsou et al., 2019). Enjoyment also arises from prosocial action that makes individuals feel socially connected to the cause they are helping (i.e. sustainability) or allows them to foresee the impact of their contribution (Albinsson and Yasanthi Perera, 2012; Hui and Kogan, 2018). Also, when individuals have a pleasurable experience using SE services, they recognize the value of sharing services and are more likely to engage in sharing practices. Thus, we posit:

H1a. Enjoyment positively influences use of SE services.

H1b. Enjoyment positively influences SE continuance intention.

Trust exists when an individual has confidence in an exchange partner's reliability and integrity (Morgan and Hunt, 1994). It is a psychological expectation governing all SE transactions as these occur between individuals that are often complete strangers. Research has analysed the role of trust, which has proven to be essential for choosing SE services (Ballús-Armet et al., 2014; Möhlmann, 2015; Tussyadiah, 2015a). Empirical evidence also suggests that intentions to consume and provide goods or services in SE are positively influenced by trust toward peers, the digital platform, and the product being shared (Hawlitschek, Teubner and Weinhardt, 2016). Findings in the context of social networking from French et al.'s (2017) study show the relationship between trust and social capital and the contribution of both to the continued use of social networking sites. The impact of trust in CC usage has also been proven (Albinsson et al., 2019). Airbnb users (both service providers and consumers) are more likely to continue using sharing economy services and disseminate their consumption experience once trust is built (Albinsson et al., 2019; Wang et al., 2020). Also, when trust is built individuals recognize the value of sharing services and are more likely to engage in sharing practices. Thus, we hypothesize that:

H2a. Trust positively influences use of SE services.

H2b. Trust positively influences SE continuance intention.

Sense of community is theorized in this study as a sense of belonging and identification with the community. It rests upon ideas of relatedness, expectation of fitting into a group and being a part of it, feelings of acceptance by the group, and a willingness to do something beneficial for the group (McMillan and Chavis, 1986). Indeed, sense of community was found to be an important driver for collaborative consumption and sharing in non-monetary contexts and an outcome of sharing (Albinsson and Yasanthi Perera, 2012). Evidence shows that sense of community has a positive impact on user satisfaction and the likelihood of choosing a car-sharing option again (Möhlmann, 2015). It is also a strong motivation for livestream engagement (Hilvert-Bruce et al., 2018) and knowledge sharing in social networking sites (Mojdeh et al., 2018). In the context of social networking tourism sites, individuals use the website not to establish deep relationships with others but to have valuable connections that give them the opportunity to gather information about their destination and find a free place to stay. (French et al., 2017). When individuals experience sense of belonging to a community, they recognize the value of sharing services and are more likely to engage in sharing practices. Thus, we hypothesize:

H3a. Sense of community positively influences use of SE services.

H3b. Sense of community positively influences SE continuance intention. 
Social Influence is defined as the extent to which an individual perceives that important persons of reference believe he or she should use sharing services (Venkatesh et al., 2012).

When choosing SE services, individuals might experience acceptance or disapproval from friends and family. Individuals' decisions toward sharing services will also be affected by online reviewers, usually total strangers. Consequently, review quality is used by individuals to enhance their knowledge on a sharing service and better assess it (Zhao et al., 2018). Furthermore, high quality and consistent reviews allow individuals to associate with strangers of reference providing online reviews, assuring community integration. In both cases, individuals accept the influence of important persons of reference by complying with a specific behaviour and accepting common orientation when engaging in sharing activities. Direct and indirect forms of social influence on individuals' sharing behaviour have been identified by previous research (e.g. Bellotti et al., 2015; Hawlitschek, Teubner, \& Gimpel, 2016; Lutz, Hoffmann, Bucher, \& Fieseler, 2018; K. Zhao et al., 2018). Amongst them are individuals' social environment, reciprocation, persuasion, socials referrals (Kong et al., 2020), and social utility (Wang et al., 2020). When individuals perceive that their behaviour is supported by important persons of reference, they recognize the value of sharing services and are more likely to engage in sharing practices. Therefore, the fourth hypotheses read as follows:

H4a. Social influence positively influences use of SE services.

H4b. Social influence positively influences SE continuance intention.

\subsection{Environmental context hypotheses}

The idea that SE services are environmentally friendly is intrinsically related to sustainability. Choosing SE services is believed to reduce consumption because they make use of the idle resource capacity and diminish the manufacture of new products (Stokes et al., 2014; Tussyadiah, 2015a). Moreover, SE is an ecological option as it preserves natural resources and is energetically efficient (Albinsson et al., 2019). SE provides a sustainable mode of consumption essential for reducing negative environmental impacts (Piscicelli et al., 2015) and an option for those guided by ideology concerns such as anti-consumption or the preference for greener consumption (Eckhardt et al., 2010). Research has shown that increasing awarness of sustainability issues among Millenials translates into empathetic feelings toward SE services (Hwang and Griffiths, 2017). Contradictory findings indicate that although SE offers additional forms of consumption, it does not disrupt prevailing forms (Martin, 2016). Instead, it adjusts and adapts itself to the legal requirements of each specific sector (Geissinger et al., 2019). Research also suggests that collaborative effort is required to control and measure externalities caused by SE and minimize negative environmental and social impacts such as the inefficient use of resources, tax evasion, and housing shortages (Leung et al., 2019). When individuals can see the impact of their behaviour toward a sustainable environment, they recognize the value of sharing services and are more likely to engage in sharing practices. Therefore, we hypothesize that:

H5a. Sustainability positively influences use of SE services.

H5b. Sustainability positively influences SE continuance intention.

\subsection{Economic context hypotheses}

While using SE services individuals improve their financial situation, either because they receive extra money or save money. These are external rewards that prompt the use of SE services. In previous studies, economic benefits are the main expected outcome reported by participants in SE (Lee et al., 2019) and a major driver for participants' intention to use SE services (Lee et al., 2018). Economic value and reward were also found to be a motivation of hosts' continued use intention toward SE services (French et al., 2017; Wang et al., 2020), and can be used to reinforce hosts' engagement in sharing activities by meeting 
or even exceeding expected economic outcomes (Lee et al., 2019). Economic benefits include price, money saving, reduced costs, financial flexibility, and lower ownership costs (Hamari et al., 2015; Lamberton and Rose, 2012; Tussyadiah, 2015b; Wang, Xiang, et al., 2019). When individuals experience economic benefits, they recognise the value of the sharing service and are more likely to engage in sharing practices. Therefore, we hypothesize that:

H6a. Economic benefits positively influence use of SE services.

H6b. Economic benefits positively influence SE continuance intention.

The monetization of excess inventory is one of the economic drivers behind the sharing economy as per the Owyang, J., Tran, C., \& Silva (2013) market report. Monetization or making financial profit from personal property, such as homes, cars, bicycles, driveways, skills, or other idle or underutilized assets is the basis of the sharing economy (Lampinen et al., 2015). Evidence from a qualitative study with Airbnb hosts indicates that monetization of unused space helps hosts select guests according to their preferences and control the volume and type of demand (Ikkala and Lampinen, 2015). When individuals make financial profit from personal property, they recognize the value of the sharing service and are more likely to engage in sharing practices. This leads us to the following hypotheses:

H7a. Monetization positively influences use of SE services.

H7b. Monetization positively influences SE continuance intention.

\subsection{Functional context hypotheses}

Utility from using SE services derives from avoiding initial purchase costs and maintenance costs and the possibility of using products otherwise not affordable, or, in the case of hosts, utility is connected to maintenance costs reduction by sharing more and owning less. It is an external reward that prompts the use of SE services. In fact, consumers prefer to avoid the burdens of ownership but expect more advantages (European Economic and Social Committee, 2014). For instance, while measuring the utility of sharing against ownership in car-sharing, findings from Lamberton \& Rose (2012) show that the price of sharing and the inconvenience of having to learn different car controls and setting the respective features to meet user preferences (technical costs) have a negative influence on the likelihood of choosing a sharing option. On the other hand, deal value perceived by the customer (transaction utility) and the number of places where cars are at a consumer's disposal (mobility utility) have a positive effect on the likelihood of choosing a sharing option. Utility is also instrumental for explaining participants' actions and decisions in crowdsourcing (Koch, 2017). Substitutability of SE services in comparison with other nonsharing options like ownership, has also an impact on the likelihood to choose SE services (Lamberton and Rose, 2012; Möhlmann, 2015). Utility is valued as an important attribute of SE services driving individuals to choose SE products or services and the sharing economy as substitutes for traditional products or services and traditional markets. Findings of Tsou et al. (2019) suggest that high utilitarian value from SE services can raise consumers' intention to continue using SE services. When individuals experience utility, they recognize the value of sharing services and are more likely to engage in sharing practices. This leads us to the following hypotheses:

H8a. Utility positively influences use of SE services.

H8b. Utility positively influences SE continuance intention.

Internet availability is an external trigger of use of SE services. As a technological platform itself, the Internet is creating more accessible and efficient alternative forms of consumption such as sharing, borrowing, and lending among individuals (Belk, 2014b; Davidson et al., 2018). The Internet enables consumers to perform tasks faster and autonomously, eliminating the need for additional products and 
services (Radka and Margolis, 2011). Internet technology reduces the costs of transactions and matches consumers and service providers in real time (Benkler, 2004; Mair and Reischauer, 2017). The Internet is now critical for communication and accessing information in everyday life. Moreover, all communication between consumers and service providers is Internet-mediated from first contact to payment (Gupta et al., 2019; Lu et al., 2019). When individuals experience the abovementioned benefits, they recognise the value of sharing services and are more likely to engage in sharing practices. Accordingly, we hypothesize that:

H9a. Internet capability positively influences use of SE services.

H9b. Internet capability positively influences SE continuance intention.

Smartphones and tablets are external triggers of the use of SE services. They offer permanent and speedy internet connection, providing prompt access to information and services, regardless of time and space. Smartphone locating capabilities allow exact location of an individual or entity. Several applications employing these positioning features are available online and can be downloaded directly onto a smartphone. These applications are revolutionizing the transportation industry, enhancing ride and car sharing: consumers can locate a car in their immediate surroundings and promptly visualize the route to walk to the vehicle on the smartphone screen (Möhlmann, 2015). Smartphones are more efficient while obtaining user-tailored information during travel planning (Huang et al., 2017), they guide people to and around cities and their attractions, enhance leisure experiences (Kirova and Vo Thanh, 2018), and negotiate immediate visitor needs. These new devices enable consumers to make informed and sustainable choices regarding resources and their alternative uses (Haucke, 2017; Pitt et al., 2011). They also facilitate product sharing among consumers on a massive scale (Jiang and Tian, 2015). When individuals experience the abovementioned benefits, they recognize the value of sharing activities and are more likely to engage in sharing activities. This leads us to the following hypotheses:

H10a. Mobile device capability positively influences use of SE services.

H10b. Mobile device capability positively influences SE continuance intention.

\subsection{Use behaviour}

In fact, after accepting technology mediated SE services, individuals begin to actually use them. During this stage the assessment occurs of the benefits and impacts of use experience, which will increase the likelihood of continuing to use SE services. A recurrent and sustained use of SE services will contribute to the formation of a decentralized network of service providers and consumers, vital for a successful SE platform (Wang, Lin, et al., 2019). Furthermore, recurrent and continued use will allow individuals to capitalize economic benefits and obtain the advantages of a product or service without the burdens of ownership. As with other technologies, the promise of SE depends on the use of its services (Bhattacherjee, 2001; Shaikh and Karjaluoto, 2015). If individuals do not recognize the value of using SE, it is likely that they will stop using SE services. This leads us to the following hypothesis:

H11. Use behaviour positively influences SE continuance intention.

3.5.1 The mediating effect of use behaviour between individuals' motivations and SE continuance intention

We argue that individuals' motivations are fundamental to support their continued use of SE services through SE use. Organizational context use has been proven to be a mediator in the relationships amongst technology, organizational and environment contexts, and SE continuance intention (Martins et al., 2019). We posit a similar role for SE use at the individual level. When using SE services individuals are intrinsically 
motivated by social and environmental concerns, but also extrinsically motivated by external rewards associated with the economic and functional contexts that lead to separate outcomes. Both types of motivations address the satisfaction of real needs. When individuals satisfy their real needs, they recognize the value of SE services and perceive use of SE services to be more positive. Consequently, greater use of SE services will increase the likelihood of continuing to use SE services.

\section{Social and environmental context hypotheses}

Individuals using SE services need and want an experience that is both fun and memorable (Hwang and Griffiths, 2017). Individuals experience enjoyment from interacting with others (Barnes and Mattsson, 2017) and through prosocial action (Hui and Kogan, 2018); Trust is a psychological expectation required to share with total strangers. Individuals need to have confidence in other users and in a service provider's ability to deliver a good service and take care of their needs (Wang et al., 2020). Sense of community and social influence address the innate needs to connect with others and act based on principles. Research has proven that individuals are more willing to share when they belong to a group with similar interests and become actively involved with the local community (Hilvert-Bruce et al., 2018; Mojdeh et al., 2018); at the same time, having one's decisions secured by important persons of reference facilitates individuals' decision making (Zhao et al., 2018). Sustainability concerns are addressed when individuals perceive that using SE services might help to preserve natural resources and is more energy efficient. It is then more likely that they increase their use of SE services (Albinsson and Yasanthi Perera, 2012). Memorable and meaningful use experiences and offering the opportunity to interact with others are important drivers of use behaviour in the sharing economy. Moreover, individuals seek to connect use with opinions that they respect to help them identify things they personally value, but also avoiding waste and destruction of value. When individuals experience these benefits, they will increase their use of SE services, and consequently the likelihood of continuing to use SE services will also increase.

H1c. The relationship between enjoyment and SE continuance intention is mediated by use behaviour. H2c. The relationship between trust and SE continuance intention is mediated by use behaviour.

H3c. The relationship between sense of community and SE continuance intention is mediated by use behaviour.

H4c. The relationship between social influence and SE continuance intention is mediated by use behaviour.

H5c. The relationship between sustainability and SE continuance intention is mediated by use behaviour.

\section{Economic and functional context hypotheses}

Economic benefits, the possibility to monetize idle resources, and utility are desirable extrinsic rewards. Individuals participating in the sharing economy improve their financial situation, either by saving or earning extra money (Lee et al., 2018). They can also monetize idle resources using valuable personal items as a source of additional income (Lampinen et al., 2015); they avoid initial purchase costs and maintenance costs, or obtain access to products otherwise not affordable. Therefore, individuals using SE services feel less dependent on companies and consequently more skilled. Their sense of empowerment and autonomy is reinforced by internet and mobile device capabilities. These technologies enable consumers to make informed and sustainable choices regarding resources and their alternative uses (Haucke, 2017; Pitt et al., 2011), allowing them to participate when they want and need and self-organize their time (Radka and Margolis, 2011). When individuals experience these benefits, they will increase use of SE services, and consequently the likelihood of continuing to use SE services will also increase. Thus, we hypothesize: 
H6c. The relationship between economic benefits and SE continuance intention is mediated by use behaviour.

H7c. The relationship between monetization and SE continuance intention is mediated by use behaviour. H8c. The relationship between utility and SE continuance intention is mediated by use behaviour.

H9c. The relationship between internet capability and SE continuance intention is mediated by use behaviour.

H10c. The relationship between mobile device capability and SE continuance intention is mediated by use behaviour.

\section{Research methods}

\subsection{Sample and data collection}

An online survey was used to collect data. A prior test was conducted within a group of 30 individuals, not included in the main study, to examine whether the respondents experienced difficulty understanding the questions, as well as to test the reliability and validity of the scales. As the survey was administered in Portugal, the English version was independently translated into Portuguese by a professional translator. At the beginning, the survey provided a clear description of the sharing economy and examples to better target respondents. Then, statements representing the independent, dependent, and control variables (age and gender) were presented. Respondents were asked to indicate the extent to which they agreed with the statements. Finally, respondents were asked to provide general information and demographic data.

Data were collected using an online survey targeting users who already had experience with digital platforms in different sectors: accommodation, car and ride sharing, professional services, renting and selling pre-owned goods. The survey provided a clear description and examples of the sharing economy, to identify sharing economy users experienced in accessing products and services, renting or selling privately owned goods using digital platforms. An e-mail invited subjects to participate. 307 responses were collected, and 51 surveys were eliminated due to incomplete answers. 256 valid responses were left for subsequent analysis (143 early respondents and 113 late respondents). Of the 256 participants, 3\% were service providers, 6\% were consumers and 91\% played both roles. As most respondents uses SE platforms to access, rent and sell privately owned goods, it would be more accurately to say that our sample focus on consumers of crowdsourced goods and services, partaking in both the demand and supply sides (Benoit et al., 2017). Table 2 shows respondents' characteristics. $50.8 \%$ were men; almost $47 \%$ were older than 35 years old, and $49.2 \%$ were undergraduate students.

Table 2 - Descriptive statistics of respondents' characteristics

\begin{tabular}{llll}
\hline Measure & Value & Frequency & \% \\
\hline \multirow{2}{*}{ Gender } & Female & 126 & 49.2 \\
& Male & 130 & 50.8 \\
\hline \multirow{3}{*}{ Age } & $<20$ & 3 & 1.2 \\
& $20-24$ & 20 & 7.8 \\
& $25-29$ & 35 & 13.7 \\
\hline \multirow{2}{*}{ Education } & $30-35$ & 79 & 30.9 \\
& $>35$ & 119 & 46.5 \\
\hline
\end{tabular}




\subsection{Development of measures}

Measures were derived from prior research and wording was slightly adapted to fit the research context. Whereas content validity is assured by literature review, research variables are operationalized according to Appendix B. All items were measured using a seven-point range scale. Enjoyment, trust, sense of community, social influence, sustainability, economic benefits, monetization, utility, internet capability, mobile device capability, use behaviour, and continuance intention were measured on an interval ranging from "strongly disagree" to "strongly agree". Gender and age were included as control variables in the research model.

\section{Data analysis}

\subsection{Preliminary analysis}

Non-response bias was assessed by comparing early and late respondent groups. Kolmogorov-Smirnov $(\mathrm{K}-\mathrm{S})$ test results revealed an absence of non-response bias and as shown in Table 3, differences between sample distributions of the two groups were not statistically significant (Ryans, 1974). As data were selfreported and respondents were asked to rate their perceptions on several variables, common method bias may arise (Shiau et al., 2020). It was assessed with two procedures. First, we used Harman's onefactor test and found that none of the factors individually explained the majority of the variance (Podsakoff et al., 2003; Podsakoff and Organ, 1986), i.e., the first factor explains $40.0 \%$ of the variance. Second, we used a marker-variable technique (Chin et al., 2012; Lindell and Whitney, 2001), which showed a theoretical variable in the research model. This irrelevant marker had $0.040(4.0 \%)$ as the maximum shared variance with other variables, a value considered low according to Johnson, Rosen, \& Chang (2011). No significant common method bias was found.

Table 3 - Early and late respondents

\begin{tabular}{lccccc}
\hline \multirow{2}{*}{ Constructs } & \multicolumn{2}{c}{ Early (n=143) } & \multicolumn{2}{c}{ Later (n=113) } & Kolmogorov-Smirnov (K-S) \\
& Mean & S.D. & Mean & S.D. & P-value \\
\hline Enjoyment (Enj) & 4.924 & 1.078 & 4.979 & 1.307 & 0.519 \\
Trust (Tru) & 4.586 & 1.132 & 4.782 & 1.138 & 0.279 \\
Community (Com) & 4.402 & 1.230 & 4.618 & 1.377 & 0.134 \\
Social influence (SI) & 3.658 & 1.359 & 3.513 & 1.465 & 0.321 \\
Sustainability & 4.954 & 1.258 & 4.821 & 1.497 & 0.552 \\
Economic benefits (EC) & 5.069 & 1.294 & 4.941 & 1.485 & 0.985 \\
Monetization (Mon) & 5.103 & 1.278 & 5.053 & 1.222 & 0.968 \\
Utility (Uti) & 4.158 & 1.357 & 4.470 & 1.402 & 0.457 \\
Internet capability (IC) & 6.270 & 1.044 & 6.112 & 1.141 & 0.325 \\
Mobile device capability (MDC) & 5.558 & 1.439 & 5.417 & 1.479 & 0.676 \\
Use behaviour (UB) & 4.050 & 1.442 & 4.011 & 1.581 & 0.952 \\
Continuance intention (INT) & 4.702 & 1.670 & 4.582 & 1.695 & 0.667 \\
\hline
\end{tabular}

\subsection{Data Analysis Procedures}

Data were carefully assessed to detect missing values, suspicious response patterns, outliers, and data distribution (Hair et al., 2014). The research model was estimated and validated using the variance-based Partial Least Squares Path Modelling (PLS-PM) technique. Suitable for structural equation modelling (SEM), prediction, and theory building, PLS-PM analyses and assesses the significance of causal relationships among a set of latent variables. This technique seeks to maximize the explained variance in endogenous constructs and the predictive power of exogenous constructs (Hair et al., 2011). PLS-PM is not particularly demanding in terms of original data distribution and sample size, achieving good results 
with small samples (Hair et al., 2012). It is also appropriate for studying complex models with several constructs (Chin, 1998). Since our aim is to predict use behaviour and continuance intention in the emergent phenomenon of the sharing economy, and data distribution was not normal ( $p<0.01$ based on Kolmogorov-Smirnov's test), PLS is the most appropriate method for this study (Hair et al., 2014).

SmartPLS 3.0 software was used to assist in the process (Ringle et al., 2015) and the two-step approach recommended by Anderson \& Gerbing (1988) was followed. First, the global model fit was assessed using the standardized root mean square residual (SRMR), an approximate measure of model fit that quantifies the discrepancy between the empirical and estimated covariance matrices (Khan et al., 2019). SRMR values below 0.08 suggest that the discrepancy is not substantial (Henseler et al., 2016), suggesting a tenable model fit. Then, the measurement model was first tested for reliability and validity, and then the structural model was assessed. This approach tests the required psychometric properties of the scales used to measure the variables in the model, assuring valid assumptions concerning the strength and direction of the relationships among the variables (Wixom and Watson, 2001).

The analysis of each indicator's reliability, composite reliability (CR), convergent validity of indicators associated with latent variables, and discriminant validity is included in the assessment of the reflective measurement model. Single indicator reliability was measured through each resulting loading, with 0.7 being the required threshold of indicator reliability (Henseler et al., 2009). Composite reliability assesses indicator suitability to define a latent variable and the threshold required is 0.70 (Hair et al., 2012). Cronbach's Alpha Coefficient supplements the analysis (Gefen and Straub, 2005), however, limitations to this measure have been pointed out by Hair et al. (2012). Average variance extracted (AVE) was used to assess convergent validity. AVE scores are expected to exceed 0.50 (Hair et al., 2011). Verification of indicator loading significance is an important complementary analysis.

Discriminant validity is the degree to which a latent variable's indicators diverge from other latent variable indicators which form part of the model (Hair et al., 2019). Two criteria were used to assess discriminant validity. Traditional metrics of discriminant validity include the observation of cross-loadings, as it requires a certain latent variable to share more variance with associated indicators than with those related to other latent variables of the model (Hulland, 1999). Additionally, the presence of discriminant validity is traditionally confirmed when the square root of the AVE for each construct is greater than the correlations between the construct in question and all the other constructs (Fornell and Larcker, 1981). However, recent research has proposed the replacement of traditional metrics by the Heterotrait-Monotrait Ratio of correlations (HTMT) as an alternative approach to assess discriminant validity (see Henseler, Ringle, \& Sarstedt, 2015). If the value of the HTMT is lower than 0.9 , discriminant validity is then confirmed.

Analysis of the structural model includes the assessment of the determination coefficient, R2. This coefficient represents the amount of variance of each latent endogenous variable explained by the model. R2 parameters of $0.75,0.50$ or 0.25 are labelled as substantial, moderate, and weak, respectively (Hair et al., 2011). Multicollinearity issues amongst independent variables are detected using the variance inflation factor (VIF). Absence of multicollinearity is suggested when VIF is less than the recommended threshold of 5 (Sarstedt et al., 2014). The analysis continues with the observation of the structural model's path coefficients, signals, magnitudes, and statistical significance. The bootstrap resampling method was used to estimate the statistical significance of path coefficients (Henseler et al., 2009), with 500 iterations of resampling (Chin, 1998). Mediation is assessed following the guidelines of Zhao, Lynch, \& Chen (2010). Indirect effects and its significance are first assessed, as a significant indirect effect is the main prerequisite to establish the presence of a mediating effect. We then assess the significance of direct effects, and whenever both effects are significant, we calculate the product of indirect and direct effects. 


\section{Results}

SRMR results (0.050) support a tenable model fit. Presented below are the assessments of both measurement and structural models.

\subsection{Evaluation of the measurement model}

Table 4 shows that all constructs exceed the suggested thresholds, with CR values ranging from 0.878 to 0.974, AVE values ranging from 0.737 to 0.957 , and except for UB3, all item loadings exceeded 0.70 , suggesting adequate convergent validity. UB3 loading is quite close to 0.7 and above the minimum (0.4) required by Hair, J. F., Hult, G. T. M., Ringle, C. M., \& Sarstedt (2014), and was therefore not eliminated from the model.

Table 4 - Quality criteria and factor loadings

\begin{tabular}{|c|c|c|c|c|c|c|}
\hline Constructs & Item & Loading & AVE & CR & CA & $t$-value \\
\hline \multirow[t]{4}{*}{ Enjoyment (Enj) } & Enj1 & 0.875 & 0.751 & 0.923 & 0.889 & 16.353 \\
\hline & Enj2 & 0.848 & & & & 16.885 \\
\hline & Enj3 & 0.881 & & & & 18.805 \\
\hline & Enj4 & 0.862 & & & & 16.008 \\
\hline \multirow[t]{3}{*}{ Trust (Tru) } & Tru1 & 0.916 & 0.784 & 0.916 & 0.862 & 17.138 \\
\hline & Tru2 & 0.861 & & & & 11.755 \\
\hline & Tru3 & 0.879 & & & & 13.744 \\
\hline \multirow[t]{4}{*}{ Community (Com) } & Com1 & 0.867 & 0.737 & 0.918 & 0.882 & 12.511 \\
\hline & Com2 & 0.874 & & & & 12.834 \\
\hline & Com3 & 0.810 & & & & 10.875 \\
\hline & Com4 & 0.880 & & & & 13.341 \\
\hline \multirow[t]{3}{*}{ Social influence (SI) } & SI1 & 0.899 & 0.762 & 0.905 & 0.840 & 13.606 \\
\hline & $\mathrm{SI} 2$ & 0.937 & & & & 18.996 \\
\hline & $\mathrm{SI} 3$ & 0.775 & & & & 9.574 \\
\hline \multirow[t]{4}{*}{ Sustainability } & Sus1 & 0.928 & 0.829 & 0.951 & 0.932 & 18.234 \\
\hline & Sus2 & 0.917 & & & & 13.359 \\
\hline & Sus3 & 0.891 & & & & 9.349 \\
\hline & Sus4 & 0.907 & & & & 12.145 \\
\hline \multirow[t]{3}{*}{ Economic benefits (EC) } & EB1 & 0.937 & 0.848 & 0.944 & 0.911 & 26.129 \\
\hline & EB2 & 0.903 & & & & 23.123 \\
\hline & EB3 & 0.923 & & & & 24.018 \\
\hline \multirow[t]{3}{*}{ Monetization (Mon) } & Mon1 & 0.891 & 0.800 & 0.923 & 0.875 & 17.634 \\
\hline & Mon2 & 0.891 & & & & 19.532 \\
\hline & Mon3 & 0.900 & & & & 18.747 \\
\hline \multirow[t]{3}{*}{ Utility (Uti) } & Uti1 & 0.849 & 0.741 & 0.896 & 0.825 & 15.218 \\
\hline & Uti2 & 0.902 & & & & 20.017 \\
\hline & Uti3 & 0.831 & & & & 15.008 \\
\hline \multirow[t]{3}{*}{ Internet capability (IC) } & IC1 & 0.966 & 0.924 & 0.973 & 0.959 & 24.995 \\
\hline & IC2 & 0.968 & & & & 23.914 \\
\hline & IC3 & 0.950 & & & & 19.491 \\
\hline \multirow[t]{3}{*}{ Mobile device capability (MDC) } & MDC1 & 0.964 & 0.926 & 0.974 & 0.960 & 32.368 \\
\hline & MDC2 & 0.969 & & & & 36.092 \\
\hline & MDC3 & 0.955 & & & & 27.711 \\
\hline \multirow[t]{4}{*}{ Use behaviour (UB) } & UB1 & 0.881 & 0.644 & 0.878 & 0.814 & 20.309 \\
\hline & UB2 & 0.883 & & & & 21.242 \\
\hline & UB3 & 0.699 & & & & 11.980 \\
\hline & UB4 & 0.730 & & & & 14.632 \\
\hline \multirow[t]{4}{*}{ Continuance intention (INT) } & INT1 & 0.966 & 0.957 & 0.989 & 0.985 & 67.735 \\
\hline & INT2 & 0.986 & & & & 81.817 \\
\hline & INT3 & 0.985 & & & & 100.235 \\
\hline & INT4 & 0.975 & & & & 80.758 \\
\hline
\end{tabular}

As shown in Table 5, the square roots of AVEs (diagonal elements) are larger than the correlation between each pair of constructs (off-diagonal elements), indicating proper discriminant validity. Analysis of the cross-loadings table in Appendix $\mathrm{C}$ reveals that indicator loadings are larger than cross-loadings, providing additional support for discriminant validity. HTMT ratios are all below the recommended threshold of 0.9 (see Table 6), thus supporting discriminant validity. 
Table 5 - The square root of AVE (in bold diagonally) and factor correlation coefficients

\begin{tabular}{lllllllllllllll}
\hline & Mean & SD & Enj & Tru & Com & SI & Sus & EB & Mon & Uti & IC & MDC & UB & INT \\
\hline Enj & 4.948 & 1.183 & $\mathbf{0 . 8 6 7}$ & & & & & & & & & & & \\
Tru & 4.673 & 1.136 & 0.594 & $\mathbf{0 . 8 8 6}$ & & & & & & & & & \\
Com & 4.498 & 1.299 & 0.527 & 0.506 & $\mathbf{0 . 8 5 9}$ & & & & & & & & \\
SI & 3.594 & 1.406 & 0.450 & 0.388 & 0.510 & $\mathbf{0 . 8 7 3}$ & & & & & & & & \\
Sus & 4.895 & 1.367 & 0.487 & 0.389 & 0.554 & 0.374 & $\mathbf{0 . 9 1 1}$ & & & & & & & \\
EB & 5.013 & 1.381 & 0.497 & 0.434 & 0.550 & 0.392 & 0.591 & $\mathbf{0 . 9 2 1}$ & & & & & & \\
Mon & 5.081 & 1.251 & 0.457 & 0.333 & 0.401 & 0.249 & 0.440 & 0.626 & $\mathbf{0 . 8 9 4}$ & & & & & \\
Uti & 4.296 & 1.383 & 0.454 & 0.405 & 0.449 & 0.331 & 0.468 & 0.484 & 0.518 & $\mathbf{0 . 8 6 1}$ & & & & \\
IC & 6.200 & 1.088 & 0.501 & 0.365 & 0.257 & 0.171 & 0.381 & 0.442 & 0.491 & 0.304 & $\mathbf{0 . 9 6 1}$ & & & \\
MDC & 5.496 & 1.456 & 0.507 & 0.319 & 0.270 & 0.210 & 0.294 & 0.470 & 0.469 & 0.342 & 0.673 & $\mathbf{0 . 9 6 2}$ & \\
UB & 4.033 & 1.502 & 0.519 & 0.432 & 0.479 & 0.464 & 0.348 & 0.530 & 0.471 & 0.560 & 0.333 & 0.421 & $\mathbf{0 . 8 0 3}$ & \\
INT & 4.649 & 1.679 & 0.538 & 0.402 & 0.374 & 0.398 & 0.379 & 0.584 & 0.521 & 0.502 & 0.468 & 0.531 & 0.648 & $\mathbf{0 . 9 7 8}$ \\
\hline Note
\end{tabular}

Note: SD: Standard deviations; Enj: Enjoyment; Tru: Trust; Com: Sense of Community; SI: Social influence; Sus: Sustainability; EB: Economic benefits; Mon: Monetization; Uti: Utility; IC: Internet capability; MDC: Mobile device capability; UB: Use behaviour; INT: Continuance intention.

Table 6 - Hetrotrait-Monotrait ratio

\begin{tabular}{|c|c|c|c|c|c|c|c|c|c|c|c|c|}
\hline Constructs & Enj & Tru & Com & SI & Sus & EB & Mon & Uti & IC & MDC & UB & INT \\
\hline \multicolumn{13}{|l|}{ Enj } \\
\hline Tru & 0.675 & & & & & & & & & & & \\
\hline Com & 0.586 & 0.574 & & & & & & & & & & \\
\hline SI & 0.520 & 0.453 & 0.596 & & & & & & & & & \\
\hline Sus & 0.529 & 0.428 & 0.605 & 0.418 & & & & & & & & \\
\hline EB & 0.551 & 0.487 & 0.615 & 0.448 & 0.638 & & & & & & & \\
\hline Mon & 0.517 & 0.379 & 0.451 & 0.288 & 0.477 & 0.698 & & & & & & \\
\hline Uti & 0.528 & 0.474 & 0.518 & 0.395 & 0.530 & 0.560 & 0.610 & & & & & \\
\hline IC & 0.540 & 0.397 & 0.271 & 0.188 & 0.394 & 0.471 & 0.534 & 0.343 & & & & \\
\hline MDC & 0.547 & 0.347 & 0.286 & 0.235 & 0.303 & 0.502 & 0.510 & 0.387 & 0.701 & & & \\
\hline UB & 0.591 & 0.509 & 0.563 & 0.564 & 0.383 & 0.605 & 0.553 & 0.669 & 0.363 & 0.462 & & \\
\hline INT & 0.573 & 0.433 & 0.391 & 0.437 & 0.386 & 0.616 & 0.560 & 0.557 & 0.481 & 0.545 & 0.710 & \\
\hline
\end{tabular}

Note: Enj: Enjoyment; Tru: Trust; Com: Sense of Community; SI: Social influence; Sus: Sustainability; EB: Economic benefits; Mon: Monetization; Uti: Utility; IC: Internet capability; MDC: Mobile device capability; UB: Use behaviour; INT: Continuance intention.

The criteria for construct reliability, indicator reliability, convergent validity, and discriminant validity were fulfilled, legitimizing the choice of the scales used for measurement (Möhlmann, 2015).

\subsection{Evaluation of the structural model}

The research model explains $50.4 \%$ of the variation in use behaviour and $57.9 \%$ of the variation in continuance intention. VIF ranges from 1.099 (lowest) to 2.518 (highest), indicating absence of multicollinearity. The analysis of hypotheses and construct relationships was based on the examination of path coefficients, their signal, and statistical significance, as illustrated in Figure 2. 
Figure 2 - Structural model results.

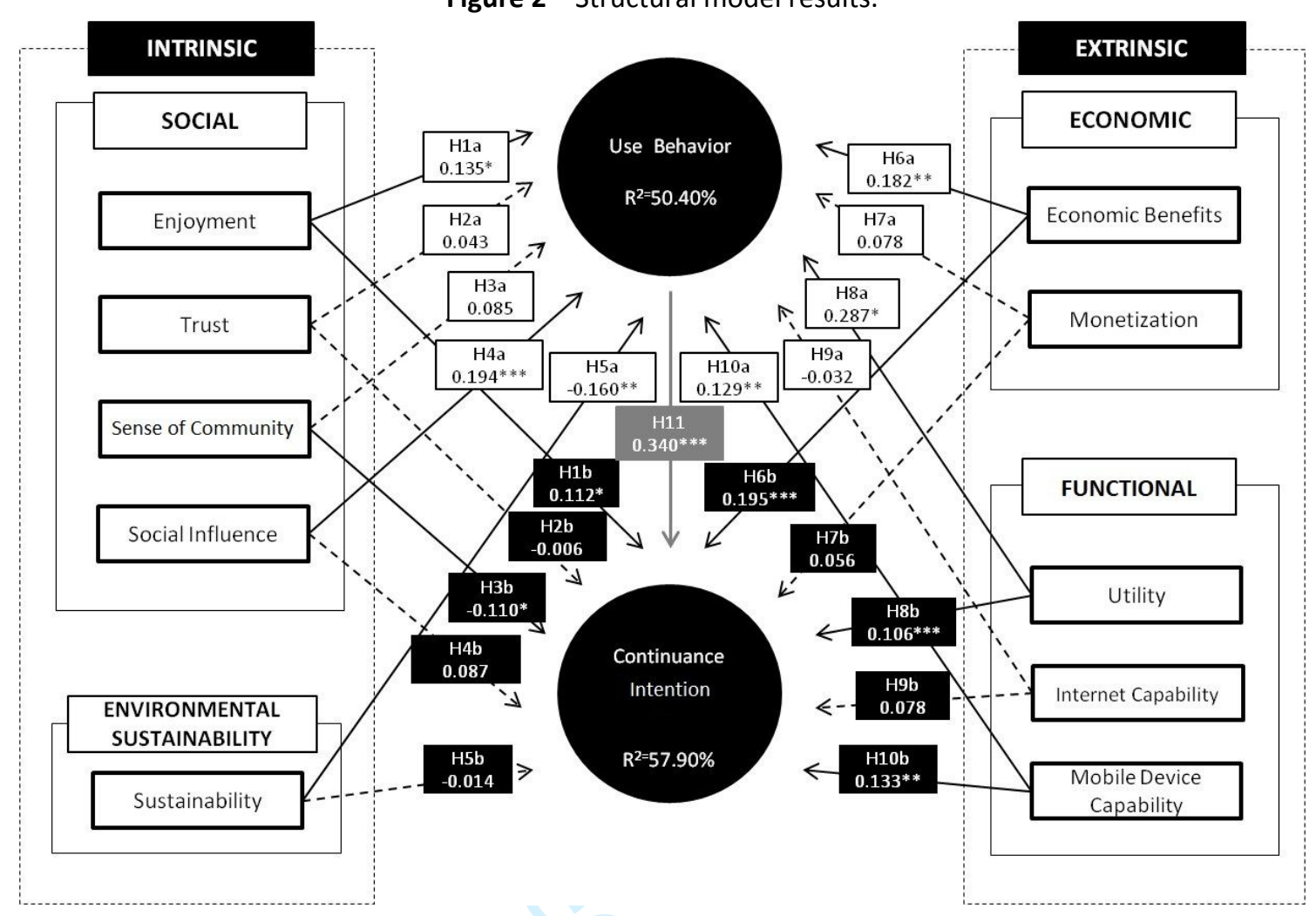

Note: ${ }^{* *} \mathrm{p}$ value $<0.01 ;{ }^{* *} \mathrm{p}$ value $<0.05 ;{ }^{*} \mathrm{p}$ value $<0.10 ;$ significant. Dashed line arrow represents not statically significant path coefficients.

Our findings on use behaviour were as follows: (i) enjoyment $(\hat{\beta}=0.135$, $\mathrm{t}$-value $=1.938, \mathrm{p}$-value $<0.10$ ) and social influence $(\hat{\beta}=0.194, \mathrm{t}$-value $=3.564, \mathrm{p}$-value $<0.01)$ exerted a positive and statistically significant effect on use behaviour, supporting $\mathrm{H} 1 \mathrm{a}$ and $\mathrm{H} 4 \mathrm{~A}$. Trust $(\hat{\beta}=0.043, \mathrm{t}$-value $=0.656, \mathrm{p}$ value $>0.10)$ and sense of community $(\hat{\beta}=0.085, t$-value $=1.150, p$-value $>0.10)$ exerted a positive influence on use behaviour, but not statistically significant. Thus, $\mathrm{H} 2 \mathrm{a}$ and $\mathrm{H} 3 \mathrm{a}$ are not supported. (ii) sustainability $(\hat{\beta}=-0.160, \mathrm{t}$-value $=2.247, \mathrm{p}$-value $<0.05)$ exerted a negative and statistically significant effect on use behaviour. Thus, $\mathrm{H} 5 \mathrm{a}$ is not supported. (iii) economic benefits $(\hat{\beta}=0.182$, $\mathrm{t}$-value $=2.664, \mathrm{p}$ value $<0.05$ ) exerted a positive and statistically significant effect on use behaviour, supporting $\mathrm{H} 6 \mathrm{a}$, while monetization $(\hat{\beta}=0.078, \mathrm{t}$-value $=1.120, \mathrm{p}$-value $>0.10$ ) exerted a positive effect on use behaviour, but not statistically significant. Thus, $\mathrm{H} 7 \mathrm{a}$ was not supported. (iv) utility $(\hat{\beta}=0.287$, $\mathrm{t}$-value $=4.285$, $\mathrm{p}$ value $<0.10)$ and mobile device capability $(\hat{\beta}=0.129$, $\mathrm{t}$-value $=2000, \mathrm{p}$-value $<0.05)$ exerted a positive and statistically significant effect on use behaviour, supporting $\mathrm{H} 8 \mathrm{a}$ and $\mathrm{H} 10 \mathrm{a}$, while internet capability $(\hat{\beta}=$ 0.032 , $t$-value $=0.549, p$-value $>0.10$ ) exerted a positive effect on use behaviour, but not statistically significant. Thus, H9a was not supported.

Our findings on continuance intention were as follows: (i) enjoyment $(\hat{\beta}=0.112$, $t$-value $=1,683, p$ value $<0.10$ ) exerted a positive and statistically significant effect on continuance intention, supporting H1b. Sense of community $(\hat{\beta}=-0.110$, $\mathrm{t}$-value $=1.750, \mathrm{p}$-value $<0.10)$ exerted a negative and statistically significant effect on continuance intention. Thus, support was not found for H3b. Trust $(\hat{\beta}=-0.006, \mathrm{t}-$ value $=0.103, \mathrm{p}$-value $>0.10)$ and social influence $(\hat{\beta}=0.087$, $\mathrm{t}$-value $=1.574, \mathrm{p}$-value $>0.10)$ exerted a nonstatistically significant effect on continuance intention. Thus, $\mathrm{H} 2 \mathrm{~b}$ and $\mathrm{H} 4 \mathrm{~b}$ were not supported. (ii) sustainability $(\hat{\beta}=-0.014, \mathrm{t}$-value $=0.216, \mathrm{p}$-value $>0.10)$ exerted a non-statistically significant effect on continuance intention. Thus, H5b was not supported. (ii) economic benefits $(\hat{\beta}=0.195$, t-value $=2.606, \mathrm{p}$ value $<0.01)$ exerted a positive and statistically significant effect on continuance intention, supporting $\mathrm{H} 6 \mathrm{~b}$, while monetization $(\hat{\beta}=0.056, \mathrm{t}$-value $=0.870, \mathrm{p}$-value $>0.10$ ) exerted a positive but non-statistically significant effect on continuance intention. Thus, $\mathrm{H} 7 \mathrm{~b}$ was not supported. (iv) utility $(\hat{\beta}=0.106$, $\mathrm{t}$ - 
value=1.809, $\mathrm{p}$-value $<0.01)$ and mobile device capability $(\hat{\beta}=0.133$, t-value=1.946, $\mathrm{p}$-value<0.05) exerted a positive and statistically significant effect on continuance intention, supporting $\mathrm{H} 8 \mathrm{~b}$ and $\mathrm{H} 10 \mathrm{~b}$, while internet capability $(\hat{\beta}=0.078$, $\mathrm{t}$-value $=1.417, \mathrm{p}$-value $>0.10)$ exerted a positive but not statistically significant effect on continuance intention. Thus, H9b was not supported. (v) use behaviour $(\hat{\beta}=0.034$, t-value=4.918, $p$-value $<0.01$ ) exerted a positive and statistically significant effect on continuance intention, supporting $\mathrm{H} 11$.

In summary, with respect to use behaviour, hypotheses $\mathrm{H} 1 \mathrm{a}, \mathrm{H} 4 \mathrm{a}, \mathrm{H} 6 \mathrm{a}, \mathrm{H} 8 \mathrm{a}$, and $\mathrm{H} 10 \mathrm{a}$ were supported and hypotheses $\mathrm{H} 2 \mathrm{a}, \mathrm{H3a}, \mathrm{H} 5 \mathrm{a}, \mathrm{H} 7 \mathrm{a}$, and $\mathrm{H} 9 \mathrm{a}$ were not supported. Furthermore, regarding continuance intention, hypotheses $\mathrm{H} 1 \mathrm{~b}, \mathrm{H} 6 \mathrm{~b}, \mathrm{H} 8 \mathrm{~b}, \mathrm{H} 10 \mathrm{~b}, \mathrm{H} 11$ were supported and hypotheses $\mathrm{H} 2 \mathrm{~b}, \mathrm{H} 3 \mathrm{~b}, \mathrm{H} 4 \mathrm{~b}, \mathrm{H} 5 \mathrm{~b}$, $\mathrm{H} 7 \mathrm{~b}$, and H9b were not supported.

\subsection{Mediation testing}

The study explores the mediation effects of use behaviour. Hypotheses $\mathrm{H} 1 \mathrm{c}$ to $\mathrm{H} 10 \mathrm{c}$ posit that use of SE services mediates the effect of individuals' motivations on SE continuance intention. Following the procedures explained in Section 5.2, we obtained the results reported in Table 7. Both indirect and direct effects of enjoyment, economic benefits, utility, and mobile device connectivity on SE continuance intention are significant and point in the same direction ( $\mathrm{x} b \mathrm{~b} \mathrm{c}$ is positive), thereby supporting $\mathrm{H} 1 \mathrm{c}$, $\mathrm{H} 6 \mathrm{c}, \mathrm{H} 8 \mathrm{c}$, and $\mathrm{H} 1 \mathrm{Oc}$ and confirming complementary mediation. Although the indirect effects of social influence and sustainability on SE continuance intention are significant, direct effects are not. $\mathrm{H} 4 \mathrm{c}$ and $\mathrm{H} 5 \mathrm{C}$ are thus supported, confirming the presence of indirect-only mediation. Only the direct effect of sense of community on SE continuance is significant. Therefore, $\mathrm{H} 3 \mathrm{c}$ is not supported and evidence of non-mediation is provided. No mediating effects of use behaviour were found between trust, monetization, and internet capability on SE continuance intention, meaning that $\mathrm{H} 2 \mathrm{c}, \mathrm{H} 7 \mathrm{c}$, and $\mathrm{H} 9 \mathrm{c}$ are not supported and evidence of non-mediation is provided.

Table 7 - Hypotheses testing on mediation

\begin{tabular}{|c|c|c|c|c|c|}
\hline Effect of & $\begin{array}{c}\text { Indirect effect } \\
\text { (a x b) } \\
\text { (t-value) }\end{array}$ & $\begin{array}{c}\text { Direct effect } \\
\text { (c) } \\
\text { (t-value) }\end{array}$ & $\begin{array}{c}\text { Sign } \\
(\mathrm{a} \times \mathrm{b} \times \mathrm{c})\end{array}$ & Interpretation & Conclusion \\
\hline Enj - > UB - > INT & $0.046 *(1.874)$ & $0.112 *(1.683)$ & + & Complementary mediation & H1c supported \\
\hline Tru - > UB - > INT & $0.015 \mathrm{~ns}(0.653)$ & -0.006 ns (0.096) & N.a & No effect non-mediation & $\mathrm{H} 2 \mathrm{c}$ not supported \\
\hline Com -> UB - > INT & $0.029 \mathrm{~ns}(1.128)$ & $-0.110 *(1.737)$ & N.a & Direct-only non-mediation & $\mathrm{H} 3 \mathrm{c}$ not supported \\
\hline $\mathrm{SI}$ - > UB -> INT & $0.066 * * *(2.728)$ & $0.087 \mathrm{~ns}(1.568)$ & N.a & Indirect-only mediation & H4c supported \\
\hline Sus - > UB - > INT & $-0.054 * *(2.003)$ & -0.014 ns (0.201) & N.a & Indirect-only mediation & H5c supported \\
\hline EB - > UB - > INT & $0.062 * *(2.297)$ & $0.195 * * *(2.607)$ & + & Complementary mediation & H6c supported \\
\hline Mon - > UB -> INT & $0.026 \mathrm{~ns}(1.103)$ & $0.056 \mathrm{~ns}(0.847)$ & N.a & No effect non-mediation & H7c not supported \\
\hline Uti - > UB -> INT & $0.097 * * *(3.448)$ & $0.106 *(1.796)$ & + & Complementary mediation & H8c supported \\
\hline IC - > UB - > INT & $-0.011 \mathrm{~ns}(0.543)$ & $0.078 \mathrm{~ns}(1.324)$ & N.a & No effect non-mediation & H9c not supported \\
\hline MDC - > UB - > INT & $0.044 * *(1.993)$ & $0.133 *(1.892)$ & + & Complementary mediation & H10c supported \\
\hline
\end{tabular}

\section{Discussion}

This study aims to understand the role of intrinsic and extrinsic motives on individuals' use and SE continuance through the lens of SDT, and consequently offer useful insights to brand managers and companies providing services through digital platforms on the SE. Consistent with findings at the organizational level, our findings show that individuals' SE continuance is significantly influenced by their 
use of SE services. Moreover, use and SE continuance are both intrinsic and extrinsic motivated behaviours. Extrinsic factors are more prominent than intrinsic factors in explaining both use of SE services and SE continuance. Namely, use is the major and strongest predictor of SE continuance, followed by economic benefits, mobile device capability, enjoyment, utility, and sense of community. Utility is the major and strongest predictor of use, followed by social influence, economic benefits, enjoyment, mobile device capability, and sustainability.

\section{Social context}

Enjoyment was found to have a positive and statistically significant impact on both use and SE continuance intention. These findings extend the ones from early research (i.e. Bellotti et al., 2015; Hamari et al., 2015) explaining participation in SE, and supporting findings from research on continuance intention (Gan and Li, 2018; Lin et al., 2017; Tsou et al., 2019). This suggests individuals also value hedonic motivations past the initial stage of adoption, more specifically, greater enjoyment and excitement will lead to greater use of SE services.

Trust did not exert a significant effect on either use behaviour or continuance intention. These findings are unexpected and contrary to published research findings that provide evidence for trust as a facilitator of continuance intention (Kong et al., 2020). An explanation might be that specific features should be accounted for when conceptualizing trust. Examples include service provider profile picture (Abramova et al., 2015) or other attributes of the product, familiarity with the digital platform (Mittendorf, 2018), security mechanisms offered by digital platforms, especially those related to the product being shared. Moreover, when conceptualizing trust, it is important to explicitly address trust toward peers, the digital platform or the product being shared.

Unlike Albinsson et al.'s (2019) study, which provides evidence for the impact of "we" identity on use, sense of community did not exert a significant impact on use. Also, but unexpected, sense of community has a negative impact on continuance intention. This is not consistent with previous findings on the likelihood of choosing a sharing economy service again (Möhlmann, 2015). Findings might indicate that a high sense of community inhibits SE continuance intention. One possible explanation might be that renting or selling personal goods and accessing products and services in a sustained manner, individuals become members of several communities, making it difficult to accept the influence of a single community or creating a sense of identification with a single community (Cheung et al., 2011).

Social influence was found to have a positive and statistically significant effect on use behaviour. Following utility, social influence was the second strongest predictor of use. In line with (Lutz et al., 2018) study, our results show norms are extremely important and that the greater the support provided by important persons of reference, the greater the use of SE services. This means that the intention to continue to use SE services is not contingent on social approval. Moreover, this findings are in line with Lamberton and Rose (2012) research, which shows that benefits accrued in the form of support by important groups of reference do not have a significant effect on consumers' propensity to choose commercial sharing rather than an ownership option. Likewise, Lin et al. (2017) research also provides evidence for the lack of significant influence of social influence on the use of Airbnb services.

\section{Environmental context}

Sustainability has a negative and statistically significant effect on use behaviour. Although evidence of effect is provided, the sign is reversed. This finding is not shared by Albinsson et al. (2019), who find that perceived sustainability is the strongest predictor of use of four different SE services. Research on sharing 
economy suggests that while digital platforms facilitate access to goods and services, they also increase consumption. The findings of our study might suggest that individuals with high environmental concerns may restrain use of SE services. While unexpected, these results are consistent with the conceptualization of sustainable consumption by Ozanne \& Ballantine (2010), which emphasizes acts of rejecting and reducing. Similar findings in relation to satisfaction with P2P accommodation were obtained by Tussyadiah (2016). Guests advocating a sustainable lifestyle had a less satisfying stay. Ultimately, this may also indicate that individuals do not choose SE services for environmental reasons. Findings related to sustainability's effect on continuance intention were not statistically significant.

\section{Economic context}

Findings from our study show that economic benefits are the third strongest predictor of use of SE services. This is consistent with early research (Hamari et al., 2015; Lamberton and Rose, 2012; Tussyadiah, 2015a), suggesting that saving money and improving one's financial situation are the most expected outcomes of individuals using SE services. Economic benefits not only explain intention to participate in the sharing economy (Lee et al., 2018), but also predict use and SE continuance intention. Our study shows that economic benefits are the main extrinsic reward explaining SE continuance intention, supporting the results of previous studies (French et al., 2017; Wang et al., 2020).

The effects of monetization on use and continuance intention are not significant.

\section{Functional context}

Utility is the strongest predictor of SE use. Findings related to utility are consistent with early research positing the influence of utility on use of SE services (Lamberton \& Rose, 2012; Möhlmann, 2015). This means maximalization of utility is a powerful extrinsic motivation responsible for SE use. Individuals believe that sharing is as good as owning and that they prefer sharing economy over the traditional economy. Our study also provides evidence for the positive effect of utility on SE continuance intention, demonstrating that intention to continue to use a SE is extrinsically motivated by utility, in a way that it well substitutes ownership. However, utility plays a lesser role when compared to use. Similarly to published research utility is outplayed by enjoyment while explain SE continuance intention (Tsou et al., 2019).

The effects of internet capability on use and continuance intention are not significant. Findings show that although individuals find the internet useful and convenient, other external factors lead to increased use and greater continuance intention. These findings echo the results presented by Möhlmann (2015).

Findings related to mobile device capability are consistent with early research positing the influence of mobile device capability on use of SE services (Möhlmann, 2015). Our study also provides evidence for the positive effect of mobile device capability on SE continuance intention, demonstrating that higher instrumental value from using mobile devices while using SE services fosters individuals' intention to continue using SE services (Tsou et al., 2019).

Results from our study provide evidence for the positive influence of use on continuance intention. Results show that greater use of SE services will lead to greater continuance intention. Greater use will allow individuals to accrue the benefits of using SE services and recognize their value, which in turn will increase individuals' engagement on sharing activities and consequently continuance intention. 
more likely to increase their use of SE services if they experience a memorable use of SE services and are supported by important people of reference, allowing them to foresee the impact of their contribution, and providing the chance to improve their financial situation (either by saving money or earning extra money and avoiding the burdens of ownership). The recurrent use of SE services will allow individuals to accrue the benefits of SE services, which will increase the likelihood to continuing to use SE services. Therefore, enjoyment, social influence, sustainability awareness, economic benefits, utility, and availability of mobile devices are fundamental in explaining use and SE continuance intention. On one hand, each type of motivation directly affects individuals' use of SE services. On the other hand, the effect of use between enjoyment, economic benefits, utility, mobile device capability and SE continuance intention is complementary, indicating that use is a mediator, consistent with our theoretical framework (Zhao et al., 2010). Furthermore, the presence of a significant direct effect can indicate an omitted mediator (Zhao et al., 2010). This possibility might be further investigated in future work. Notwithstanding, complementary mediation of use between enjoyment, economic benefits, utility, mobile device capability, and SE continuance intention is confirmed. Use effects between social influence and sustainability on SE continuance intention are indirect only, meaning that the effects of these two types of motivation on SE continuance are contingent on use. In the case of sustainability, greater sustainability concerns will lead to less use, and greater use will lead to less intention to continue to use. The effect of sense of community on SE continuance is direct only. Neither direct nor indirect effects of trust, monetization, and internet capability on SE continuance were significant, suggesting the need for further examination.

\subsection{Theoretical implications}

Implications for theory are twofold. First, our study contributes to the academic literature on continuance intention in the context of the sharing economy, showing that along with satisfaction and confirmation, use plays a crucial role in explaining continuance intention. The relationship between use and continuance intention is already explored in IT continuance, but to our knowledge it is a novel contribution at the individual level, in the context of the sharing economy. Most studies on the sharing economy focus on adoption, namely on motivations and drivers to participate in the sharing economy (i.e. Festila \& Müller, 2017; Moeller \& Wittkowski, 2010; Tussyadiah, 2015a), the role of trust, trustworthiness of peers, and reputation (i.e Abramova et al., 2015; Hawlitschek, Teubner, \& Weinhardt, 2016; Teubner, Hawlitschek, \& Dann, 2017), and on the platforms (i.e., Sutherland \& Jarrahi, 2018; Teubner \& Flath, 2015; Trang, Busse, Schmidt, Falk, \& Marrone, 2015). Although earlier research has provided useful and important insights for understanding adoption, the current study extends the understanding of SE by exploring motivations for post-adoption behaviour. Previous studies on post-adoption behaviour have not explored the relationship between use and continuance intention in the context of the sharing economy, having usually focused on antecedents of confirmation and satisfaction, or combining social and technical factors to explain continuance intention. Furthermore, the examination of use as a mediator strengthens the role of continued use as a major driver for individuals' engagement with SE (Bhattacherjee, 2001). Therefore, our findings enrich the understanding of individuals' SE continuance intention. Second, using SDT as a theoretical lens provides a deeper understanding of individuals' real needs and tackles the real reasons behind use and intention to continue to use SE services. The validated model combines a comprehensive set of motives supported by research and derived from social, environmental, economic, and functional contextual characteristics of SE, demonstrating the benefits of using an all-inclusive approach to assess use and SE continuance intention.

\subsection{Practical implications}

Our findings suggest that use of SE services and continuance intention are intrinsic and extrinsic motivated behaviours. Our model will allow brand managers and companies providing services through digital 
platforms to address individuals' needs in order to stimulate voluntary engagement in persistent SE practices. They must keep in mind that extrinsic factors are prominent predictors of use and continuance intention for individuals acting both as service providers and consumers; namely economic benefits, utility, and mobile device capability. Accordingly, economic reward and cost-effective services should continue to be reinforced as benefits associated with the use of sharing economy options, as they are amongst the three main expected outcomes of individuals acting both as consumers and service providers. Brand managers should advertise and promote utility of SE services, stressing its advantages in relation to the traditional market: greater flexibility and convenience, and quicker and independent access to products and services otherwise not accessible. Additionally, our study confirms individuals' reliance on mobile devices, especially regarding continued used. Mobile devices are decisive to empower individuals to participate at need and self-organize their time, as they help to blur time and space limitations.

Findings also confirm the relevance of mechanisms fostering intrinsic motivated behaviour, addressing individuals' needs for social influence, enjoyment, sense of community and sustainability. Social influence is the strongest intrinsic factor explaining use, followed by enjoyment. This means that the use of SE services shows acceptance and compliance with orientation and norms of important persons of reference (i.e., friends, family, and workplace colleagues) of individuals' social groups. Moreover, individuals expect more than a normal shopping task, they expect a fun and exciting use experience. Brand managers and companies providing SE services should advertise the use of their SE services as a practise that renders the values of its users, e.g., modernity or innovativeness. Brand managers can put in place a communication strategy that emphasizes the values that set their customers apart and implement it in their system design, keeping it up to date with features that provide a memorable use experience.

The unexpected findings related to the effect of sustainability on use may indicate that consumers with high sustainability concerns may not choose sharing economy services based on negative effects such as housing shortages and tax evasion, which are often associated with this alternative way of consumption. Digital platforms should carefully brand their services associating technology with positive environmental impacts and greener behaviours, communicating use of SE services as an ecological and energy efficient option that preserves natural resources and avoids loss of value to counter the idea of increased consumption and other negative impacts.

Use is the most important antecedent of SE continuance intention. Brand managers should focus on offering a use experience that makes individuals feel good about their choices, by addressing the needs previously mentioned, namely utility, social influence, economic benefits, enjoyment, mobile device capability, and sustainability concerns. Addressing individuals' real needs allows brand managers to provide their customers with benefits they recognize as valuable and start to capitalize on them. Consequently, individuals will be more willing to engage in voluntary and persistent SE practices. Moreover, mediating analysis revealed that use mediation effects are indirect only regarding sustainability and social influence. This means that the effect of these two drivers on SE continuance intention is contingent on use. In order to address sustainability concerns, brand managers should clearly communicate impact on the environment of using their SE services during individuals' experience, and likewise for the status values inherent to the brand.

The mediation effect of use between enjoyment, economic benefits, utility, and mobile device capability and SE continuance intention is complementary. According to Zhao et al. (2010), this indicates that a mediator might be missing from our theoretical framework. However, the mediator role of use is confirmed. For the abovementioned reasons, this study offers a framework that will allow practitioners to maintain existing customers and build up a decentralized network of customers, focusing on individuals 
acting both as consumers and service providers. Practitioners may find it beneficial to increase use of services provided, which will make their business viable and successful in the long term.

Finally, this study informs the consumer so that the sharing economy can develop its potential alongside an economy based on the ownership of private property (Heinrichs and Grunenberg, 2013).

\subsection{Limitations and future research}

There is still a great deal to do in order to better understand the opportunities and limitations of the sharing economy. This study was carried out in Portugal. Future research should assess these issues in other countries, replicating our investigation and comparing the results. Different services and products might be added, or the study can be confined to a specific context. This study addresses two of the three types of motivation proposed in the SDT framework (Ryan and Deci, 2000b): intrinsic and extrinsic. Future research should consider the role of amotivation in post-adoption behaviours.

Our sample includes individuals acting as consumers and service providers (prosumers) and a small percentage of one-sided users ( $3 \%$ acting as service providers and $6 \%$ acting as consumers). We acknowledge this fact as a limitation of our work. Future work should explore the role of prosumers, using adequate means for targeting and differentiating this role, but also seek differences in motivations among the three groups of users: service providers, consumers, and prosumers.

The number of hypotheses not supported suggests that the investigation of complex constructs such as social influence, trust, sense of community, sustainability, monetization, and Internet capability might benefit from some refinement in conceptualization and the use of qualitative data for a more detailed analysis. The analysis of use should be complemented with other measures of use, such as duration and intensity, and with data provided by qualitative methods of research. Other control variables should also be considered, such as experience of using SE services or familiarity with SE platforms. Further research should also consider the role of other mediators.

\section{Conclusions}

The sharing economy is becoming popular all over the world. However, due to its novelty it has received limited attention in the literature so far. Most studies on sharing economy focus on adoption. There is little empirical support for use and continuance intention in the novel context of the sharing economy. Furthermore, the mediating effects of use between individuals' motivations and their SE continuance intentions has hardly been explored. To address these gaps, a context tailored research model is developed and grounded on Self-determination theory (SDT). The model is empirically tested based on a sample of 256 respondents. Both intrinsic and extrinsic motivations are found to be major predictors of use of SE services and SE continuance intention, while intrinsic motivation play a lesser role.

Enjoyment, social Influence, sustainability, economic benefits, utility, and mobile device capability are found to be statistically significant in explaining use behaviour. However, trust, sense of community, monetization, and internet capability are not believed important in explaining actual use of sharing economy services. The findings of our study might suggest that individuals with high environmental concerns may restrain their use of SE services. Results also indicate that enjoyment, sense of community, economic benefits, utility, mobile device capability, and use behaviour have a direct effect on SE continuance. Trust, social influence, sustainability, monetization, and internet capability are not believed important in explaining continuance intention. This study shows that continuance intention is influenced by current use of SE services, which, to our knowledge, is a novel contribution in the context of the Sharing Economy. Moreover, the study emphasizes the mediation effect of use between intrinsic and extrinsic 
factors and SE continuance intention. This study provides further evidence that the assessment of SE continuance intention benefits from an approach grounded on SDT including social, environmental, economic, and functional factors derived from SE context, and provides researchers and practitioners with richer insights.

\section{References}

Abramova, O., Shavanova, T., Fuhrer, A., Krasnova, H. and Buxmann, P. (2015), “Understanding the Sharing Economy: The Role of Response to Negative Reviews in the Peer-to-peer Accommodation Sharing Network", ECIS 2015 Completed Research Papers. Paper 1., available at: http://aisel.aisnet.org/ecis2015_cr.

Acquier, A., Daudigeos, T. and Pinkse, J. (2017), "Promises and paradoxes of the sharing economy: An organizing framework", Technological Forecasting and Social Change, Elsevier, Vol. 125 No. July, pp. 1-10.

Albinsson, P.A., Perera, B.Y., Nafees, L. and Burman, B. (2019), "Collaborative Consumption Usage in the US and India: An Exploratory Study", Journal of Marketing Theory and Practice, Routledge, Vol. 27 No. 4, pp. 390-412.

Albinsson, P.A. and Yasanthi Perera, B. (2012), "Alternative marketplaces in the 21st century: Building community through sharing events", Journal of Consumer Behaviour, Vol. 11 No. 4, pp. 303-315.

Anderson, J.C. and Gerbing, D.W. (1988), "Structural Equation Modeling in Practice: A Review and Recommended Two-Step Approach", Psychological Bulletin, Vol. 103 No. 3, pp. 411-423.

Ballús-Armet, I., Shaheen, S., Clonts, K. and Weinzimmer, D. (2014), "Peer-to-Peer Carsharing", Transportation Research Record: Journal of the Transportation Research Board, Vol. 2416, pp. 2736.

Bandura, A. (2001), "Social cognitive theory: an agentic perspective", Annual Review of Psychology, Vol. 52, pp. 1-26.

Bardhi, F. and Eckhardt, G.M. (2012), “Access-Based Consumption: The Case of Car Sharing: Table 1.", Journal of Consumer Research, Vol. 39, available at:https://doi.org/10.1086/666376.

Barnes, S.J. and Mattsson, J. (2017), "Understanding collaborative consumption: Test of a theoretical model", Technological Forecasting and Social Change, Vol. 118, pp. 281-292.

Belk, R. (2014a), "Sharing versus pseudo-sharing in web 2.0", Anthropologist, Vol. 18 No. 1, pp. 7-23.

Belk, R. (2014b), "You are what you can access: Sharing and collaborative consumption online", Journal of Business Research, available at:https://doi.org/10.1016/j.jbusres.2013.10.001.

Bellotti, V., Ambard, A., Turner, D., Gossmann, C., Demkova, K. and Carroll, J.M. (2015), “A Muddle of Models of Motivation for Using Peer-to-Peer Economy Systems", Proceedings of the 33rd Annual ACM Conference on Human Factors in Computing Systems - $\mathrm{CHI}$ '15, available at:https://doi.org/10.1145/2702123.2702272.

Benkler, Y. (2004), "Sharing Nicely : On Shareable Goods and the Emergence of Sharing as a Modality of Econom", The Yale Law Journal, Vol. 114 No. 2, pp. 273-358.

Benkler, Y. (2017), "Peer production, the commons, and the future of the firm", Strategic Organization, Vol. 15 No. 2, pp. 264-274.

Benoit, S., Baker, T.L., Bolton, R.N., Gruber, T. and Kandampully, J. (2017), “A triadic framework for collaborative consumption (CC): Motives, activities and resources \& capabilities of actors", Journal of Business Research, Elsevier, Vol. 79 No. May, pp. 219-227.

Bhattacherjee, A. (2001), "Understanding Information Systems Continuance: An ExpectationConfirmation Model”, MIS Quarterly, Vol. 25 No. 3, pp. 351-370.

Bhattacherjee, A. and Barfar, A. (2011), "Information Technology Continuance Research: Current State and Future Directions", Asia Pacific Journal of Information Systems, Vol. 21 No. 2, pp. 1-18.

Chasin, F. and Scholta, H. (2015), "Taking peer-to-peer sharing and collaborative consumption onto the next level - new opportunities and challenges for e-government", Twenty-Third European Conference on Information Systems.

Cheung, C.M.K., Chiu, P.Y. and Lee, M.K.O. (2011), “Online social networks: Why do students use facebook?", Computers in Human Behavior, Elsevier Ltd, Vol. 27 No. 4, pp. 1337-1343.

Chin, W. (1998), "The partial least squares approach to structural equation modeling. In G. Marcoulides(Ed.)", Modern Methods for Business Research, Lawrence Erlbaum Associates, pp. 295-336. 
Chin, W., Thatcher, J. and Wright, R. (2012), "Assessing Common Method Bias: Problems with the ULMC Technique", MIS Quarterly, Vol. 36 No. 3, pp. 1003-1019.

Cho, S., Park, C.W. and Kim, J. (2019), "Leveraging Consumption Intention with Identity Information on Sharing Economy Platforms", Journal of Computer Information Systems, Taylor \& Francis, Vol. 59 No. 2, pp. 178-187.

Cockayne, D.G. (2016), "Sharing and neoliberal discourse: The economic function of sharing in the digital on-demand economy", Geoforum, Vol. 77, pp. 73-82.

Cohen, B. and Kietzmann, J. (2014), "Ride On! Mobility Business Models for the Sharing Economy", Organization and Environment, Vol. 27 No. 3, pp. 279-296.

Davidson, A., Habibi, M.R. and Laroche, M. (2018), "Materialism and the sharing economy: A crosscultural study of American and Indian consumers", Journal of Business Research, Elsevier, Vol. 82 No. July 2015, pp. 364-372.

Davlembayeva, D., Papagiannidis, S. and Alamanos, E. (2020), “Mapping the economics, social and technological attributes of the sharing economy", Information Technology and People, Vol. 33 No. 3, pp. 841-872.

Eckhardt, G.M., Belk, R. and Devinney, T.M. (2010), “Why don't consumers consume ethically?”, Journal of Consumer Behaviour, Vol. 9, pp. 426-436.

Ek Styvén, M. and Mariani, M.M. (2020), "Understanding the intention to buy secondhand clothing on sharing economy platforms: The influence of sustainability, distance from the consumption system, and economic motivations", Psychology and Marketing, Vol. 37 No. 5, pp. 724-739.

Ertz, M., Durif, F. and Arcand, M. (2018), "A conceptual perspective on collaborative consumption", AMS Review, AMS Review, available at:https://doi.org/10.1007/s13162-018-0121-3.

Ertz, M., Lecompte, A. and Durif, F. (2017), "Dual roles of consumers: Towards an insight into collaborative consumption motives", International Journal of Market Research, Vol. 59 No. 6, pp. 725-748.

European Economic and Social Committee. (2014), "Collaborative or participatory consumption, a sustainability model for the 21st century".

Festila, M. and Müller, S.D. (2017), "The Impact of Technology-Mediated Consumption on Identity: the Case of Airbnb", Proceedings of the 50th Hawaii International Conference on System Sciences, available at: http://hdl.handle.net/10125/41157.

Fornell, C. and Larcker, D.F. (1981), "Evaluating Structural Equation Models with Unobservable Variables and Measurement Error", Journal of Marketing Research, Vol. 18 No. 1, pp. 39-50.

French, A.M., Luo, X. (Robert) and Bose, R. (2017), "Toward a holistic understanding of continued use of social networking tourism: A mixed-methods approach", Information and Management, Elsevier B.V., Vol. 54 No. 6, pp. 802-813.

Frenken, K. and Schor, J. (2017), "Putting the sharing economy into perspective", Environmental Innovation and Societal Transitions, available at:https://doi.org/10.1016/j.eist.2017.01.003.

Friedman, G. (2014), "Workers without employers: shadow corporations and the rise of the gig economy", Review of Keynesian Economics, Vol. 2 No. 2, pp. 171-188.

Gan, C. and Li, H. (2018), "Understanding the effects of gratifications on the continuance intention to use WeChat in China: A perspective on uses and gratifications", Computers in Human Behavior, Elsevier B.V., Vol. 78, pp. 306-315.

Gefen, D. and Straub, D. (2005), “A Practical Guide To Factorial Validity Using PLS-Graph: Tutorial And Annotated Example", Communications of the Association for Information Systems, Vol. 16, pp. 91109.

Geissinger, A., Laurell, C., Öberg, C. and Sandström, C. (2019), "How sustainable is the sharing economy? On the sustainability connotations of sharing economy platforms", Journal of Cleaner Production, Vol. 206, pp. 419-429.

Gupta, M., Esmaeilzadeh, P., Uz, I. and Tennant, V.M. (2019), "The effects of national cultural values on individuals' intention to participate in peer-to-peer sharing economy", Journal of Business Research, Elsevier, Vol. 97 No. September 2017, pp. 20-29.

Hair, J. F., Hult, G. T. M., Ringle, C. M., \& Sarstedt, M. (2014), Partial Least Squares Structural Equation Modeling (PLS-SEM), Sage Publisher, available at:https://doi.org/10.1108/EBR-10-2013-0128.

Hair, J.F., Ringle, C.M. and Sarstedt, M. (2011), "PLS-SEM: Indeed a Silver Bullet", The Journal of Marketing Theory and Practice, Vol. 19 No. 2, pp. 139-152.

Hair, J.F., Risher, J.J., Sarstedt, M. and Ringle, C.M. (2019), "When to use and how to report the results of PLS-SEM", European Business Review, Vol. 31 No. 1, pp. 2-24. 
Hair, J.F., Sarstedt, M., Hopkins, L. and Kuppelwieser, V.G. (2014), "Partial least squares structural equation modeling (PLS-SEM) An emerging tool in businees research", European Business Review, Vol. 26 No. 2, pp. 106-121.

Hair, J.F., Sarstedt, M., Ringle, C.M. and Mena, J.A. (2012), "An assessment of the use of partial least squares structural equation modeling in marketing research", Journal of the Academy of Marketing Science, Vol. 40 No. 3, pp. 414-433.

Hamari, J., Sjöklint, M. and Ukkonen, A. (2015), "The sharing economy: Why people participate in collaborative consumption", Journal of the Association for Information Science and Technology, available at:https://doi.org/10.1002/asi.23552.

Haucke, F. (2017), "Smartphone-enabled social change: evidence from the Fairphone case?", Journal of Cleaner Production, Vol. 197 No. Part 2, pp. 1719-1730.

Hawlitschek, F., Teubner, T. and Gimpel, H. (2016), “Understanding the sharing economy - Drivers and impediments for participation in peer-to-peer rental", Proceedings of the Annual Hawaii International Conference on System Sciences, Vol. 2016-March No. November, pp. 4782-4791.

Hawlitschek, F., Teubner, T. and Weinhardt, C. (2016), "Trust in the Sharing Economy", Swiss Journal of Business Research and Practice, Vol. 70 No. 1, pp. 26-44.

Heinrichs, H. and Grunenberg, H. (2013), "Sharing Economy - Towards a New Culture of Consumption?", Centre for Sustainability Management, p. 21.

Henseler, J., Hubona, G. and Ray, P.A. (2016), "Using PLS path modeling in new technology research: Updated guidelines", Industrial Management and Data Systems, Vol. 116 No. 1, pp. 2-20.

Henseler, J., Ringle, C.M. and Sarstedt, M. (2015), "A new criterion for assessing discriminant validity in variance-based structural equation modeling", Journal of the Academy of Marketing Science, Vol. 43 No. 1, pp. 115-135.

Henseler, J., Ringle, C.M. and Sinkovics, R.R. (2009), "The use of partial least squares path modeling in international marketing", Advances in International Marketing, Vol. 20 No. May 2014, pp. 277319.

Hermes, S., Maier, M., Hein, A., Böhm, M. and Krcmar, H. (2020), “User Roles on Peer-to-Peer Sharing Platforms: A Critical Review of the Literature and Recommended Remedies", Proceedings of the 53rd Hawaii International Conference on System Sciences, pp. 804-813.

Hilvert-Bruce, Z., Neill, J.T., Sjöblom, M. and Hamari, J. (2018), "Social motivations of live-streaming viewer engagement on Twitch", Computers in Human Behavior, Vol. 84, pp. 58-67.

Huang, C.D., Goo, J., Nam, K. and Yoo, C.W. (2017), "Smart tourism technologies in travel planning: The role of exploration and exploitation", Information and Management, Elsevier B.V., Vol. 54 No. 6, pp. 757-770.

Hui, B.P.H. and Kogan, A. (2018), "Daily Ups and Downs: An Event-Sampling Study of the Mediated Moderation of Prosocial Engagement on Well-Being", Social Psychological and Personality Science, Vol. 9 No. 6, pp. 675-688.

Hulland, J. (1999), "Use of partial least squares (PLS) in strategic management research: a review of four recent studies", Strategic Management Journal, Vol. 20 No. 2, pp. 195-204.

Hwang, J. and Griffiths, M.A. (2017), "Share more, drive less: Millennials value perception and behavioral intent in using collaborative consumption services", Journal of Consumer Marketing, Vol. 34 No. 2, pp. 132-146.

Ikkala, T. and Lampinen, A. (2015), "Monetizing Network Hospitality: Hospitality and Sociability in the Context of Airbnb", Proceedings of the 18th ACM Conference on Computer Supported Cooperative Work \& Social Computing, pp. 1033-1044.

Jiang, B. and Tian, L. (2015), "Collaborative Consumption: Strategic and Economic Implications of Product Sharing", Available at SSRN 2561907, pp. 1-41.

Johnson, R.E., Rosen, C.C. and Chang, C.H. (2011), "To Aggregate or Not to Aggregate: Steps for Developing and Validating Higher-Order Multidimensional Constructs", Journal of Business and Psychology, Vol. 26 No. 3, pp. 241-248.

Khan, G.F., Sarstedt, M., Shiau, W.L., Hair, J.F., Ringle, C.M. and Fritze, M.P. (2019), "Methodological research on partial least squares structural equation modeling (PLS-SEM): An analysis based on social network approaches", Internet Research, Vol. 29 No. 3, pp. 407-429.

Kirova, V. and Vo Thanh, T. (2018), "Smartphone use during the leisure theme park visit experience: The role of contextual factors", Information and Management, Elsevier B.V., available at:https://doi.org/10.1016/j.im.2018.11.008.

Koch, J. (2017), "A framework for the notion of 'utility' in the landscape of crowdfunding", Proceedings 
Kong, Y., Wang, Y., Hajli, S. and Featherman, M. (2020), "In Sharing Economy We Trust: Examining the Effect of Social and Technical Enablers on Millennials' Trust in Sharing Commerce", Computers in Human Behavior, Elsevier, Vol. 108 No. April 2019, p. 105993.

Krush, M.T., Pennington, J.R., Fowler, A.R. and Mittelstaedt, J.D. (2015), "Positive marketing: A new theoretical prototype of sharing in an online community", Journal of Business Research, Elsevier Inc., Vol. 68 No. 12, pp. 2503-2512.

Kumar, V., Lahiri, A. and Dogan, O.B. (2018), “A strategic framework for a profitable business model in the sharing economy", Industrial Marketing Management, Elsevier, Vol. 69 No. August, pp. 147160.

Lamberton, C.P. and Rose, R.L. (2012), "When Is Ours Better Than Mine? A Framework for Understanding and Altering Participation in Commercial Sharing Systems", Journal of Marketing, Vol. 76, pp. 109-125.

Lampinen, A., Bellotti, V., Monroy-Hernández, A., Cheshire, C. and Samuel, A. (2015), "Studying the 'Sharing Economy'", Proceedings of the 18th ACM Conference Companion on Computer Supported Cooperative Work \& Social Computing - CSCW'15 Companion, pp. 117-121.

Lang, B., Botha, E., Robertson, J., Kemper, J.A., Dolan, R. and Kietzmann, J. (2020), "How to grow the sharing economy? Create Prosumers!", Australasian Marketing Journal, Vol. 28 No. 3, pp. 58-66.

Lee, H., Yang, S.B. and Koo, C. (2019), "Exploring the effect of Airbnb hosts' attachment and psychological ownership in the sharing economy", Tourism Management, Elsevier, Vol. 70 No. February 2018, pp. 284-294.

Lee, Z.W.Y., Chan, T.K.H., Balaji, M.S. and Chong, A.Y.L. (2018), "Why people participate in the sharing economy: an empirical investigation of Uber", Internet Research, Vol. 28 No. 3, pp. 829-850.

Leung, X.Y., Xue, L. and Wen, H. (2019), "Framing the sharing economy: Toward a sustainable ecosystem", Tourism Management, Elsevier, Vol. 71 No. September 2018, pp. 44-53.

$\mathrm{Li}, \mathrm{H}$. and Wen, H. (2019), "How is motivation generated in collaborative consumption: Mediation effect in extrinsic and intrinsic motivation", Sustainability (Switzerland), Vol. 11 No. 3, available at:https://doi.org/10.3390/su11030640.

Liang, L.J., Choi, H.C. and Joppe, M. (2018), "Understanding repurchase intention of Airbnb consumers: perceived authenticity, electronic word-of-mouth, and price sensitivity", Journal of Travel and Tourism Marketing, Routledge, Vol. 35 No. 1, pp. 73-89.

Lin, H.-Y., Wang, M.-H. and Wu, M.-J. (2017), "A study of Airbnb use behavior in the sharing economy.", International Journal of Organizational Innovation, Vol. 10 No. 1, pp. 38-47.

Lindell, M.K. and Whitney, D.J. (2001), "Accounting for common method variance in cross-sectional research designs.", Journal of Applied Psychology, Vol. 86 No. 1, pp. 114-121.

Lindenberg, S. (2001), "Intrinsic Motivation in a New Light", Kyklos, Vol. 54 No. 2\&3, pp. 317-342.

Liu, F., Lim, E.T.K., Li, H., Tan, C.W. and Cyr, D. (2020), “Disentangling utilitarian and hedonic consumption behavior in online shopping: An expectation disconfirmation perspective", Information and Management, Elsevier, Vol. 57 No. 3, p. 103199.

Lu, Y., Papagiannidis, S. and Alamanos, E. (2019), "Exploring the emotional antecedents and outcomes of technology acceptance", Computers in Human Behavior, Elsevier B.V., Vol. 90, pp. 153-169.

Lusch, R.F. and Nambisan, S. (2015), "Service innovation: A service-dominant logic perspective", MIS Quarterly: Management Information Systems, Vol. 39 No. 1, pp. 155-175.

Lutz, C., Hoffmann, C.P., Bucher, E. and Fieseler, C. (2018), "The role of privacy concerns in the sharing economy", Information Communication and Society, Vol. 21 No. 10, pp. 1472-1492.

Mair, J. and Reischauer, G. (2017), "Capturing the dynamics of the sharing economy: Institutional research on the plural forms and practices of sharing economy organizations", Technological Forecasting and Social Change, Elsevier, Vol. 125 No. May, pp. 11-20.

Martin, C.J. (2016), "The sharing economy: A pathway to sustainability or a nightmarish form of neoliberal capitalism?", Ecological Economics, Elsevier B.V., Vol. 121, pp. 149-159.

Martins, R., Oliveira, T., Thomas, M. and Tomás, S. (2019), “Firms' continuance intention on SaaS use an empirical study", Information Technology and People, Vol. 32 No. 1, pp. 189-216.

McMillan, D.W. and Chavis, D.M. (1986), "Sense of community: A definition and theory. Special Issue: Psychological sense of community, I: Theory and concepts", Journal of Community Psychology, Vol. 14 No. 1, pp. 6-23.

Mittendorf, C. (2018), "Collaborative consumption: the role of familiarity and trust among Millennials", Journal of Consumer Marketing, Vol. 35 No. 4, pp. 377-391. 
Moeller, S. and Wittkowski, K. (2010), "The burdens of ownership: reasons for preferring renting", Managing Service Quality, Vol. 20 No. 2, pp. 176-191.

Möhlmann, M. (2015), "Collaborative consumption: determinants of satisfaction and the likelihood of using a sharing economy again", Journal of Consumer Behaviour, Vol. 14 No. 11, pp. 193-207.

Mojdeh, S., Head, M. and El Shamy, N. (2018), "Knowledge Sharing in Social Networking Sites: How Context Impacts Individuals' Social and Intrinsic Motivation to Contribute in Online Communities", AIS Transactions on Human-Computer Interaction, Vol. 10 No. 2, pp. 82-104.

Mont, O.K. (2002), "Clarifying the concept of product-service system", Journal of Cleaner Production, Vol. 10, pp. 237-245.

Morgan, R.M. and Hunt, S.D. (1994), "The commitment-Trust Theory of Relationship Marketing”, Journal of Marketing, Vol. 58 No. 3, pp. 20-38.

Owyang, J., Tran, C., \& Silva, C. (2013), The Collaborative Economy, ALTIMETER.

Ozanne, L.K. and Ballantine, P.W. (2010), “Application of anti-permeation technology in the oil tank farms for petrochemical plants", Journal of Consumer Behaviour, Vol. 9 No. 11, pp. 485-498.

Piscicelli, L., Cooper, T. and Fisher, T. (2015), "The role of values in collaborative consumption: Insights from a product-service system for lending and borrowing in the UK", Journal of Cleaner Production, Elsevier Ltd, Vol. 97, pp. 21-29.

Pitt, L.F., Parent, M., Junglas, I., Chan, A. and Spyropoulou, S. (2011), "Integrating the smartphone into a sound environmental information systems strategy: Principles, practices and a research agenda", Journal of Strategic Information Systems, Elsevier B.V., Vol. 20 No. 1, pp. 27-37.

Podsakoff, P.M., MacKenzie, S.B., Lee, J.Y. and Podsakoff, N.P. (2003), “Common Method Biases in Behavioral Research: A Critical Review of the Literature and Recommended Remedies", Journal of Applied Psychology, Vol. 88 No. 5, pp. 879-903.

Podsakoff, P.M. and Organ, D.W. (1986), "Self-Reports in Organizational Research: Problems and Prospects", Journal of Management, Vol. 12 No. 4, pp. 531-544.

PWC. (2017), Share Economy 2017 The New Business Model, PwC, available at: https://www.pwc.at/de/publikationen/branchen-und-wirtschaftsstudien/share-economy-report2017.pdf\%0Ahttps://www.pwc.de/de/digitale-transformation/share-economy-report-2017.pdf.

Radka, R. and Margolis, A. (2011), "Changing models of ownership and value exchange", Etnographic Praxis in Industry, pp. 214-228.

Richardson, L. (2015), "Performing the sharing economy", Geoforum, Vol. 67, pp. 121-129.

Ringle, C., Wende, S. and Becker, J. (2015), "SmartPLS 3. Bönningstedt: SmartPLS", Retrieved from Http://Www.Smartpls.Com.

Ryan, R.M. and Deci, E.L. (2000a), "Self-Determination Theory and the Facilitation of Intrinsic Motivation, Social Development and Well-Being", American Psychologist, Vol. 55 No. 1, pp. 68-78.

Ryan, R.M. and Deci, E.L. (2000b), "Intrinsic and Extrinsic motivations: Classic definitions and new directions", Contemporary Educational Psychology, Vol. 25, pp. 54-67.

Ryans, A.B. (1974), "Estimating Consumer Preferences for a New Durable Brand in an Established Product Class", Journal of Marketing Research, Vol. 11 No. 4, pp. 434-443.

Sach, A. (2015), "2015_ECIS_Sach_IT-user-aligned Business Model Innovation (ITUA) in the SE", ECIS 2015 Completed Research Papers. Paper 153., available at: http://aisel.aisnet.org/ecis2015_cr/153.

Sarstedt, M., Ringle, C.M., Smith, D., Reams, R. and Hair, J.F. (2014), "Partial least squares structural equation modeling (PLS-SEM): A useful tool for family business researchers", Journal of Family Business Strategy, Elsevier Ltd, Vol. 5 No. 1, pp. 105-115.

Shaikh, A.A. and Karjaluoto, H. (2015), "Making the most of information technology \& systems usage: A literature review, framework and future research agenda", Computers in Human Behavior, Elsevier Ltd, Vol. 49, pp. 541-566.

Shao, Z., Li, X., Guo, Y. and Zhang, L. (2020), "Influence of service quality in sharing economy: Understanding customers' continuance intention of bicycle sharing", Electronic Commerce Research and Applications, Elsevier, Vol. 40 No. October 2019, p. 100944.

Shiau, W.L., Yuan, Y., Pu, X., Ray, S. and Chen, C.C. (2020), "Understanding fintech continuance: perspectives from self-efficacy and ECT-IS theories", Industrial Management and Data Systems, Vol. 120 No. 9, pp. 1659-1689.

Shmidt, M. (2020), "Participants' interaction with sharing economy platforms in Russia", Information Technology and People, Vol. 33 No. 3, pp. 897-917.

Sorensen, F. (2002), Tourist Destination Networks - Networks of Agglomerations as a Sub-Optimal 
Network Configurations.

Stokes, K., Clarence, E., Anderson, L. and Rinne, A. (2014), Making Sense of the Uk Collaborative Economy, Nesta.

Sutherland, W. and Jarrahi, M.H. (2018), "The Sharing Economy and Digital Platforms : A Review and Research Agenda", International Journal of Information Management, Elsevier, Vol. 43 No. July, pp. 1-34.

Teubner, T. and Flath, C.M. (2015), "The Economics of Multi-Hop Ride Sharing: Creating New Mobility Networks Through IS", Business and Information Systems Engineering, available at:https://doi.org/10.1007/s12599-015-0396-y.

Teubner, T., Hawlitschek, F. and Dann, D. (2017), "Price determinants on Airbnb: How reputation pays off in the sharing economy", Journal of Self-Governance and Management Economics, Vol. 5 No. 4 , p. 53.

Trang, S., Busse, S., Schmidt, J., Falk, T. and Marrone, M. (2015), "The danger of replacing human interaction in is-driven collaborative consumption services", Twenty-Third European Conference on Information Systems.

Tsou, H.T., Chen, J.S., Chou, C.Y. and Chen, T.W. (2019), "Sharing economy service experience and its effects on behavioral intention", Sustainability (Switzerland), Vol. 11 No. 18, pp. 1-25.

Tussyadiah, I.P. (2015a), An Exploratory Study on Drivers and Deterrents of Collaborative Comsumption in Travel, edited by Publishing., S.I.Tussyadiah, I. \& Inversini, A. (Eds.), Information \& Communication Technologies in Tourism, Informatio., available at:https://doi.org/10.1007/978-3319-14343-9_59.

Tussyadiah, I.P. (2015b), "An Exploratory Study on Drivers and Deterrents of Collaborative Consumption in Travel", in Publishing., S.I. (Ed.), Information and Communication Technologies in Tourism 2015, Informatio., pp. 817-830.

Tussyadiah, I.P. (2016), "Factors of satisfaction and intention to use peer-to-peer accommodation", International Journal of Hospitality Management, Vol. 55, pp. 70-80.

Urbach, N., Smolnik, S. and Riempp, G. (2010), "An empirical investigation of employee portal success", Journal of Strategic Information Systems, Elsevier B.V., Vol. 19 No. 3, pp. 184-206.

Venkatesh, V. (2000), "Determinants of Perceived Ease of Use : Intrinsic Control, Motivation, Integrating and Emotion into the Technology Acceptance", Information Systems Research, Vol. 11 No. 4, pp. 342-365.

Venkatesh, V. and Goyal, S. (2010), "Expectation disconfirmation and technology adoption: polynomial modeling and response surface analysis", Management Information Systems, Vol. 34 No. 2, pp. 281-303.

Venkatesh, V., Morris, M.G., Davis, G.B. and Davis, F.D. (2003), "User Acceptance of Information Technology: Toward a Unified View”, MIS Quarterly, Vol. 27 No. 3, pp. 425-478.

Venkatesh, V., Thong, J.Y.L., Chan, F.K.Y., Hu, P.J.H. and Brown, S.A. (2011), "Extending the two-stage information systems continuance model: Incorporating UTAUT predictors and the role of context", Information Systems Journal, Vol. 21 No. 6, pp. 527-555.

Venkatesh, V., Thong, J.Y.L. and Xu, X. (2012), "Consumer acceptance and use of information technology : extending the unified theory of acceptance and use of technology", MIS Quarterly, Vol. 36 No. 1, pp. 157-178.

Wang, X., Lin, X. and Liu, Z. (2019), “Understanding Consumers' Post-Adoption Behavior in Sharing Economy Services", Journal of Computer Information Systems, Taylor \& Francis, pp. 1-10.

Wang, Y., Asaad, Y. and Filieri, R. (2020), "What Makes Hosts Trust Airbnb? Antecedents of Hosts' Trust toward Airbnb and Its Impact on Continuance Intention", Journal of Travel Research, Vol. 59 No. 4, pp. 686-703.

Wang, Y., Xiang, D., Yang, Z.Y. and Ma, S. (Sara). (2019), “Unraveling customer sustainable consumption behaviors in sharing economy: A socio-economic approach based on social exchange theory", Journal of Cleaner Production, Elsevier Ltd, Vol. 208, pp. 869-879.

Wen, C., Prybutok, V.V.R. and Xu, C. (2011), "An integrated model for customer online repurchase intention", Journal of Computer Information Systems, Vol. 52 No. 1, pp. 14-23.

Wixom, B.H. and Watson, H.J. (2001), "An empirical investigation of the factors affecting data warehousing success", MIS Quarterly, Vol. 25 No. 1, pp. 17-41.

Xu, X. and Gursoy, D. (2020), "Exploring the relationship between servicescape, place attachment, and intention to recommend accommodations marketed through sharing economy platforms", Journal of Travel and Tourism Marketing, Routledge, Vol. 37 No. 4, pp. 429-446. 
$\mathrm{Xu}, \mathrm{X}$. and Schrier, T. (2019), "Hierarchical effects of website aesthetics on customers' intention to book on hospitality sharing economy platforms", Electronic Commerce Research and Applications, Elsevier, Vol. 35 No. November 2018, p. 100856.

Ye, T., Alahmad, R., Pierce, C. and Robert, L.P. (2017), "Race and Rating on Sharing Economy Platforms: The Effect of Race Similarity and Reputation on Trust and Booking Intention in Airbnb", International Conference on Information Systems, available at: https://deepblue.lib.umich.edu/bitstream/handle/2027.42/138125/Teng et al. 2017 \%28ICIS 2017\%29.pdf? sequence=1\&isAllowed=y.

Zhang, L., Yan, Q. and Zhang, L. (2018), "A computational framework for understanding antecedents of guests' perceived trust towards hosts on Airbnb", Decision Support Systems, Elsevier, Vol. 115 No. October, pp. 105-116.

Zhao, K., Stylianou, A.C. and Zheng, Y. (2018), "Sources and impacts of social influence from online anonymous user reviews", Information and Management, Elsevier B.V., Vol. 55 No. 1, pp. 16-30.

Zhao, X., Lynch, J.G. and Chen, Q. (2010), "Reconsidering Baron and Kenny: Myths and truths about mediation analysis", Journal of Consumer Research, Vol. 37 No. 2, pp. 197-206. 
Appendix A - Drivers for sharing economy adoption

\begin{tabular}{|c|c|c|c|c|c|c|c|c|c|c|}
\hline & $\begin{array}{c}\text { Botsman \& } \\
\text { Rogers, } \\
2010\end{array}$ & $\begin{array}{l}\text { Ozanne and } \\
\text { Ballantine, } \\
2010\end{array}$ & $\begin{array}{l}\text { Lamberton } \\
\text { and Rose, } \\
2012\end{array}$ & $\begin{array}{c}\text { Albinsson } \\
\text { and Perera, } \\
2012\end{array}$ & $\begin{array}{l}\text { Ballús- } \\
\text { Armet et al. } \\
2014\end{array}$ & $\begin{array}{l}\text { Ikala and } \\
\text { Lampinem, } \\
2015\end{array}$ & $\begin{array}{l}\text { Tussyadiah, } \\
2015\end{array}$ & $\begin{array}{l}\text { Hamari, } \\
2016\end{array}$ & $\begin{array}{c}\text { Belloti et al } \\
2015\end{array}$ & $\begin{array}{c}\text { Möhlmann, } \\
2015\end{array}$ \\
\hline Enjoyment & $x$ & & & & & & & $x$ & $x$ & \\
\hline Trust & & & & & $x$ & & $x$ & & & $x$ \\
\hline Community & $x$ & $x$ & & $x$ & & & $x$ & & $x$ & $x$ \\
\hline Social influence & & & & & & & & & $x$ & \\
\hline Sustainability & & & & & $x$ & & $x$ & $x$ & $x$ & \\
\hline Economic benefits & & & $x$ & & & $x$ & $x$ & $x$ & & \\
\hline Monetization & & & & & & $x$ & & & & \\
\hline Utility & & & $x$ & $x$ & & & & & $x$ & $x$ \\
\hline Internet capacity & $x$ & & & & & & & & & $x$ \\
\hline Mobile device capability & & & & & & & & & & $x$ \\
\hline
\end{tabular}

24

25

26

2

29

30

31

32

$3:$

34

35

36

37

38 


\begin{tabular}{|c|c|c|c|}
\hline Constructs & Items & & Source \\
\hline \multirow{4}{*}{ Enjoyment (Enj) } & I think sharing economy is enjoyable. & Enj1 & \multirow{4}{*}{$\begin{array}{l}\text { (Hamari et al., 2015; } \\
\text { Wen et al., 2011) }\end{array}$} \\
\hline & I think sharing economy is exciting. & Enj2 & \\
\hline & I think sharing economy is fun. & Enj3 & \\
\hline & I think sharing economy is interesting. & Enj4 & \\
\hline \multirow[b]{2}{*}{ Trust (Tru) } & I think sharing economy offers trust. & Tru1 & \multirow{2}{*}{$\begin{array}{l}\text { (Möhlmann, 2015; } \\
\text { Wen et al., 2011) }\end{array}$} \\
\hline & $\begin{array}{l}\text { I think the other users of sharing economy are truthful. } \\
\text { I think sharing economy providers give trust on the service they provide. }\end{array}$ & $\begin{array}{l}\text { Tru2 } \\
\text { Tru3 }\end{array}$ & \\
\hline \multirow{3}{*}{$\begin{array}{l}\text { Sense of community } \\
\text { (Com) }\end{array}$} & $\begin{array}{l}\text { The use of sharing economy allows me to belong to a group of people with } \\
\text { similar interests. }\end{array}$ & Com1 & \multirow{3}{*}{$\begin{array}{l}\text { (Hamari et al., 2015; } \\
\text { Möhlmann, 2015) }\end{array}$} \\
\hline & $\begin{array}{l}\text { The use of sharing economy makes me feel like I'm more involved in the } \\
\text { community. }\end{array}$ & Com2 & \\
\hline & $\begin{array}{l}\text { The use of sharing economy allows me to gain recognition from community. } \\
\text { The use of sharing economy allows me to know people with similar interests. }\end{array}$ & $\begin{array}{l}\text { Com3 } \\
\text { Com4 }\end{array}$ & \\
\hline \multirow{3}{*}{ Social influence (SI) } & People who influence my behaviour think that I should use sharing economy. & SI1 & \multirow{3}{*}{$\begin{array}{l}\text { (Venkatesh et al., } \\
\text { 2003) }\end{array}$} \\
\hline & People who are important to me think that I should use sharing economy. & $\mathrm{SI} 2$ & \\
\hline & Sharing economy is a status symbol in my environment (Image). & $\mathrm{SI} 3$ & \\
\hline \multirow{4}{*}{ Sustainability (Sus) } & Sharing economy helps save natural resources. & Sus1 & \multirow{4}{*}{ (Hamari et al., 2015) } \\
\hline & Sharing economy is a sustainable mode of consumption. & Sus2 & \\
\hline & Sharing economy is efficient in terms of using energy. & Sus3 & \\
\hline & Sharing economy is environmentally friendly. & Sus4 & \\
\hline \multirow{3}{*}{ Economic benefits (EB) } & My participation in sharing economy benefits me financially. & EB1 & \multirow{3}{*}{ (Hamari et al., 2015) } \\
\hline & My participation in sharing economy can improve my economic situation. & EB2 & \\
\hline & My participation in sharing economy saves me money. & EB3 & \\
\hline Monetization (Mon) & $\begin{array}{l}\text { Sharing economy allows idle resources to be shared and often monetized. } \\
\text { Sharing economy allows me to utilize something of value as a source of profit. } \\
\text { Sharing economy allows me to monetize products that I usually don't use. }\end{array}$ & $\begin{array}{l}\text { Mon1 } \\
\text { Mon2 } \\
\text { Mon3 }\end{array}$ & $\begin{array}{l}\text { (Owyang, J., Tran, } \\
\text { C., \& Silva, 2013) }\end{array}$ \\
\hline \multirow{3}{*}{ Utility (Uti) } & I believe that sharing economy substitutes quiet well an own product. & Uti1 & \multirow{3}{*}{ (Möhlmann, 2015) } \\
\hline & I think sharing products is as good as owning products. & Uti2 & \\
\hline & I prefer sharing economy over the traditional economy. & Uti3 & \\
\hline \multirow{3}{*}{ Internet capability (IC) } & The Internet is useful to access sharing economy. & IC1 & \multirow{3}{*}{ (Möhlmann, 2015) } \\
\hline & The Internet enables me a convenient use of sharing economy. & IC2 & \\
\hline & Using the Internet increases the productive use of sharing economy. & IC3 & \\
\hline \multirow{3}{*}{$\begin{array}{l}\text { Mobile device } \\
\text { capability (MDC) }\end{array}$} & My mobile device is useful for consuming sharing economy. & MDC1 & \multirow{3}{*}{ (Möhlmann, 2015) } \\
\hline & My mobile device enables me a convenient use of sharing economy. & MDC2 & \\
\hline & Using my mobile device increases the productive use of sharing economy. & MDC3 & \\
\hline \multirow{4}{*}{ Use behaviour (UB) } & I use the sharing economy to access services instead of buying. & UB1 & \multirow{4}{*}{ (Urbach et al., 2010) } \\
\hline & I use the sharing economy to access products instead of buying. & UB2 & \\
\hline & I use the sharing economy to rent products I own. & UB3 & \\
\hline & I use the sharing economy to sell products I own. & UB4 & \\
\hline \multirow{4}{*}{$\begin{array}{l}\text { Continuance } \\
\text { (INT) }\end{array}$} & I intend to continue using sharing economy, rather than discontinue its use. & INT1 & \multirow{4}{*}{$\begin{array}{l}\text { (Bhattacherjee, } \\
\text { 2001; Venkatesh et } \\
\text { al., 2011; Venkatesh } \\
\text { and Goyal, 2010) }\end{array}$} \\
\hline & I plan to continue using sharing economy. & INT2 & \\
\hline & I will continue using sharing economy. & INT3 & \\
\hline & I predict I will continue using sharing economy in the future. & INT4 & \\
\hline
\end{tabular}

